\title{
Rapport om evaluering af psykologordningen på Mercantec
}





\section{Kolofon}

Dato

30. november 2015

Ole Dibbern Andersen

Lektor

Professionshøjskolen Metropol

Nationalt Center for Erhvervspædagogik 


\section{Indhold}

1. Indledning: om målsætning med ordningen og evalueringen ............................... 6

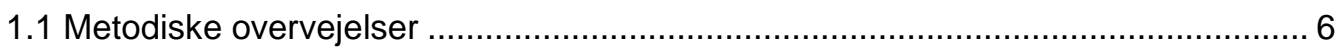

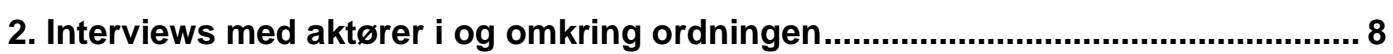

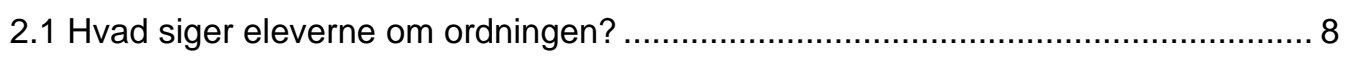

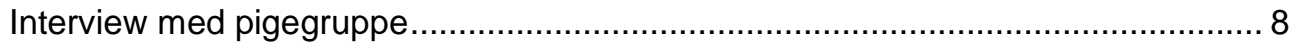

Interviews med elever i den individuelle ordning ……....................................... 10

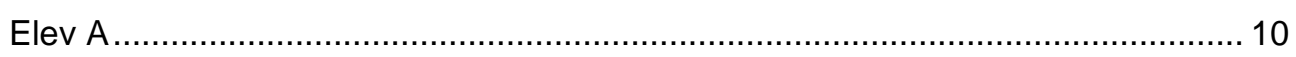

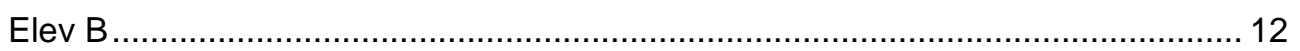

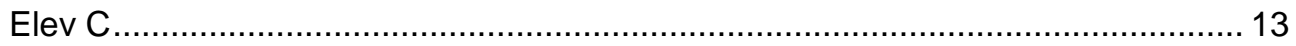

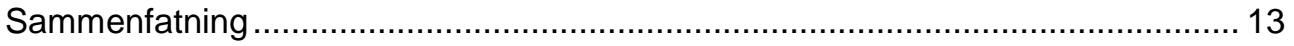

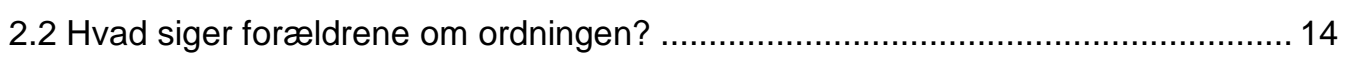

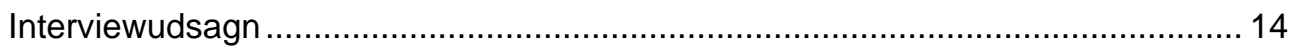

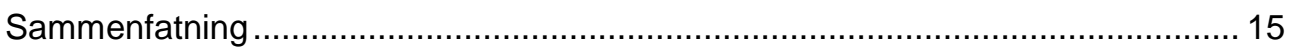

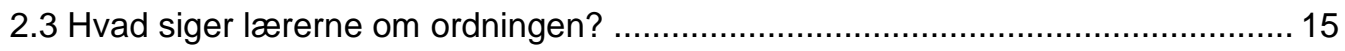

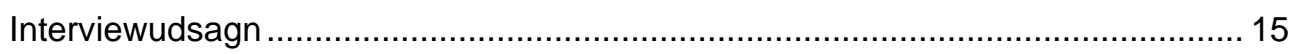

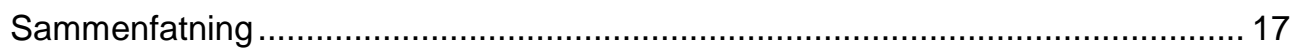

2.4 Hvad siger mentorerne, kontaktlærerne og studievejlederne om ordningen? ...... 18

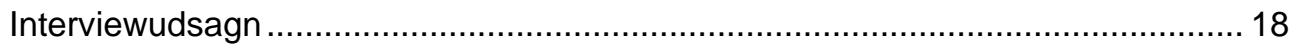

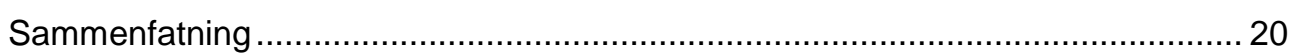

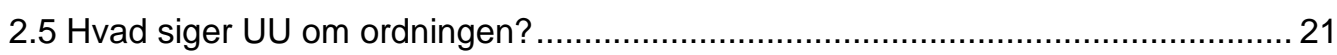

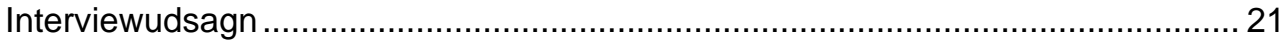

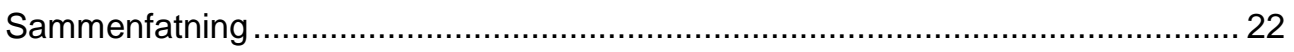

2.6 Hvad siger projektkoordinatoren om ordningen? ............................................ 23

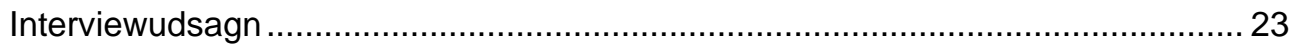

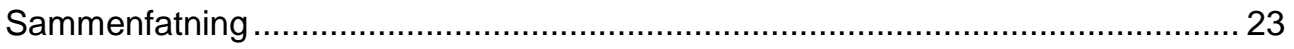

2.7 Hvad siger uddannelseslederne om ordningen? ........................................... 24

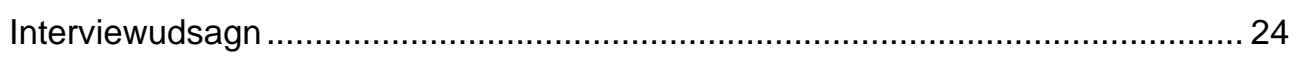

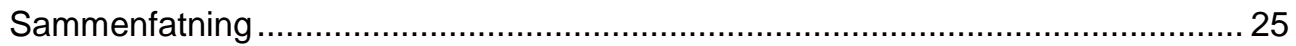

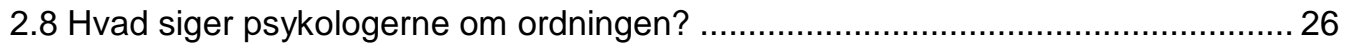

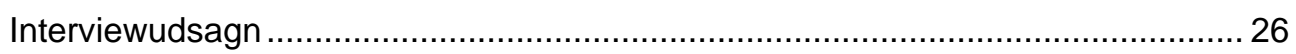

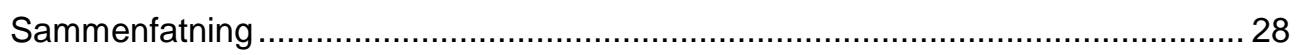

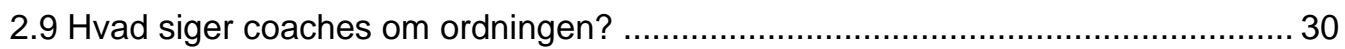

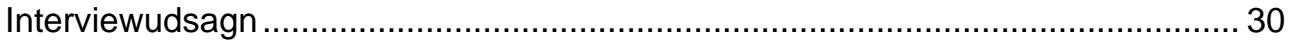

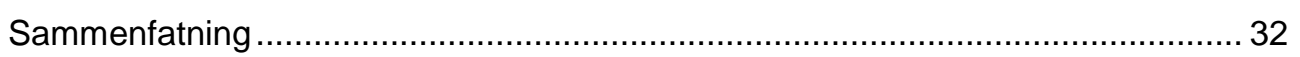

$2.10 \mathrm{Hvad}$ siger skolens ledelse om ordningen? ................................................ 33 


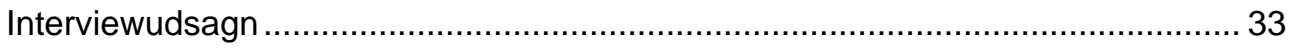

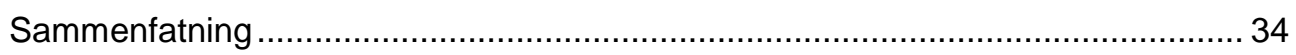

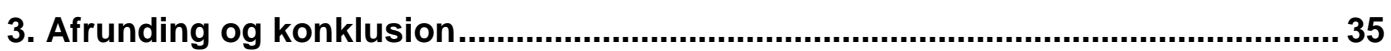




\section{Indledning: om målsætning med ordningen og evalueringen}

Denne rapport præsenterer en evaluering af den psykologordning, der har fungeret på Mercantec siden 2007.

Ordningen er finansieret af satspuljemidler fra Socialstyrelsen, der $\mathrm{i}$ to omgange har bevilget midler til etablering og drift af ordningen, først i perioden 2007-11, dernæst i perioden 2011-15.

Intentionen med ordningen har været at give elever under 25 år på erhvervsuddannelserne mulighed for at få psykologisk bistand, således at elever, der af forskellige årsager oplever problemer eller udfordringer i tilknytning til deres erhvervsuddannelsesforløb, kan støttes $i$ at tackle og løse disse, så uddannelsesforløbet ikke af disse årsager afbrydes eller forlænges unødigt.

I løbet af den tid, hvor ordningen har eksisteret, har den - som det også fremgår af de gennemførte interviews - udviklet sig markant. I ordningens tidlige fase tog den primært sigte på at tilbyde individuelle samtaler (såkaldte "konsultationer") til elever, der oplevede akutte eller mere permanente problemer i relation til uddannelsesforløbet. Med tiden er ordningen blevet udvidet, således at den i dag ud over de individuelle samtaler også rummer en række andre elementer: tættere samarbejde med coaches og (kontakt)lærere, erfaringsformidling på hjemmeside og konferencer samt intensiveret samarbejde med eksterne aktører, så som kommune og sundhedsvæsen.

Intentionen med evalueringen har været at belyse ordningen "på godt og ondt", dvs. forsøge i traditionen fra den udviklingsorienterede evaluering at afdække, hvilke svagheder og styrkesider ordningen - med de efterhånden otte års historie bag sig - måtte besidde. For at kunne gøre dette er der valgt en kvalitativ tilgang, der via enkeltinterviews og fokusgruppeinterviews har sigtet mod at belyse, hvordan samtlige aktører i og omkring ordningen beskriver og vurderer deres erfaringer med at være i kontakt med ordningen læs herom i næste afsnit.

Evalueringen har omvendt ikke haft som intention at udfolde kvantitative betragtninger $\mathrm{i}$ form af belysning af, hvilke effekter, hvilket udbytte eller hvilke anvendelsesfrekvenser ordningen måtte have. Den kvantitative evaluering er fravalgt, idet ordningen indgår i en bredere survey-undersøgelse, der er forankret hos Rambøll.

\subsection{Metodiske overvejelser}

Som nævnt ovenfor er evalueringen gennemført som en kvalitativ evaluering, med inspiration i begrebet "udviklingsorienteret evaluering".

Det centrale for denne type evaluering er - kort fortalt - at den tilstræber at skabe en viden om, hvordan et givent fænomen (her: psykologordningen ved Mercantec) faktuelt fungerer i forhold til sit formål, men samtidig har opmærksomheden rettet mod at kunne udpege, hvor og på hvilken måde aktørerne i og omkring ordningen oplever muligheder for at udvikle eller forbedre ordningen.

Det kvalitative undersøgelsesdesign har derfor været indrettet med dette som sigtepunkt, idet der er gennemført interviews med samtlige af de aktører, der blev vurderet til at have en direkte erfaring med ordningen, og som med baggrund i deres erfaringer måtte formodes at være i stand til at pege på evt. forbedringsmuligheder. 
Der er således gennemført interviews med følgende aktører:

- Elever (fokusgruppe og enkeltvis)

- Forældre

- Lærere

- Coaches

- Kontaktlærere, mentorer og studievejledere

- Uddannelsesledere

- UU

- Psykologer

- Projektkoordinatoren

- Skolens ledelse

På baggrund af en semistruktureret spørgeguide har aktørerne haft mulighed for at beskrive og vurdere deres erfaringer med ordningen. Ligeledes har aktørerne skulle udpege de forslag eller ideer de måtte anse for relevante for at kunne udvikle ordningens kvalitet.

Samtlige interviews er optaget, bearbejdet og findes i sammenfattet form i de efterfølgende afsnit, idet der er lagt vægt på at gengive de enkelte udsagn så tæt på det formulerede som overhovedet muligt.

For hver enkelt aktør afrundes afsnittet med en kort sammenfatning, der illustrerer kernen i interviewet.

Rapporten afrundes med en opsamling, hvor samtlige udsagn sammenstilles og vurderes.

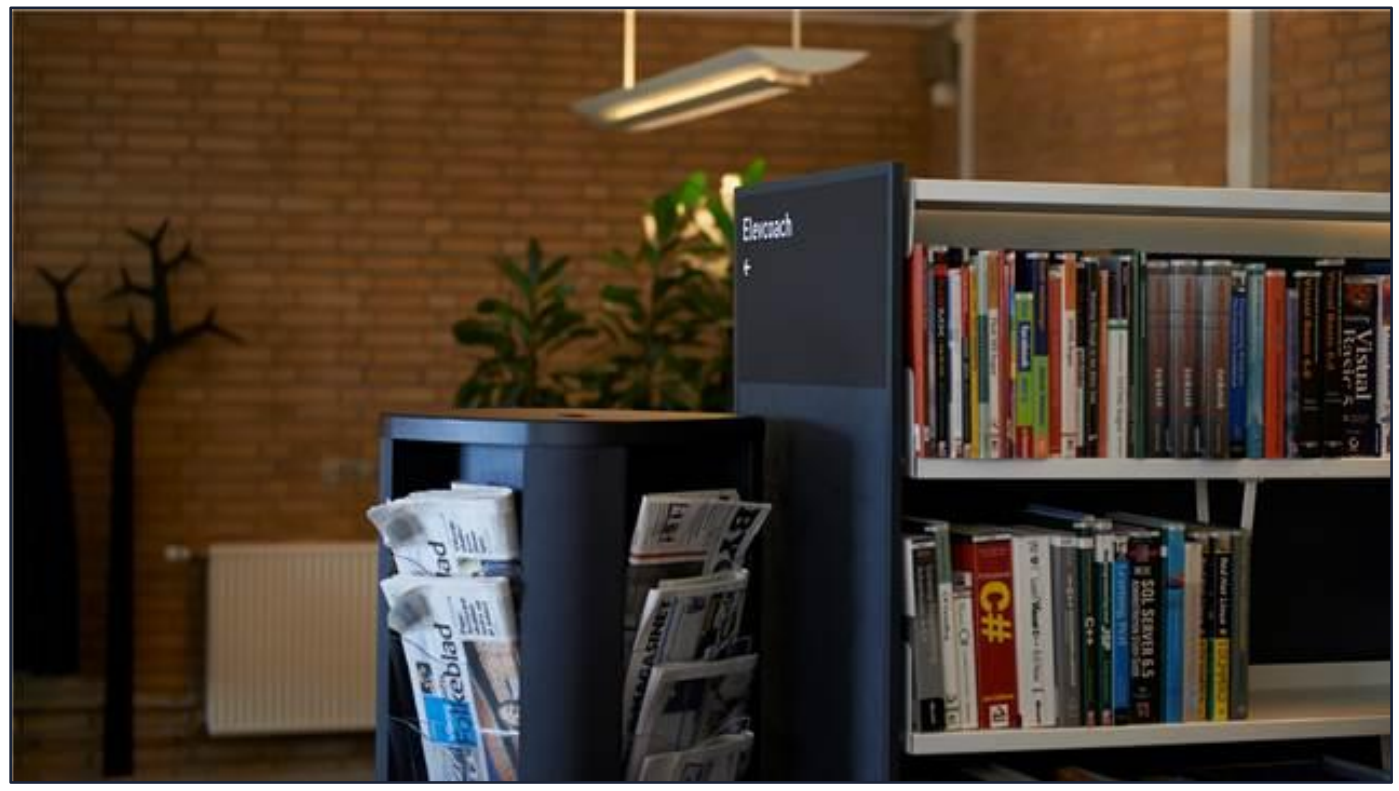




\section{Interviews med aktører i og omkring ordningen}

\subsection{Hvad siger eleverne om ordningen?}

Der er gennemført to typer af elevinterviews. Dels et fokusgruppeinterview med tre elever (piger) fra auto-afdelingen, dels en række enkeltinterviews med elever, der har haft individuelle samtaler med psykologen.

I det følgende gengives udsagn fra disse to interviewtyper.

\section{Interview med pigegruppe}

Vi er alle tre startet på auto-uddannelsens grundforløb, men på lidt forskellige tidspunkter, og har forskellig længde på vores uddannelsesplaner: 30, 30 og 40 uger. Vi har ikke lærepladser endnu.

Vi har brugt psykologordningen som gruppe, som støtte for at få mere struktur og disciplin ind i hverdagene, da vi alle har oplevet problemer med at komme op om morgenen og møde til tiden, samt engagere os i undervisningen. Vi talte også med coachen og fik struktur på ugen, så vi havde styr på det. Det er coachens skyld, at vi er kommet så langt. Det er godt at få nogle mål at gå efter, så kan man bedre agere i hverdagen. Vi arbejder med en skala, hvor vi bliver vurderet på, hvor mødestabile vi er. Det er godt med en sådan skala. Møderne kan tage 10-30 minutter, og vi tager så tiden ud af skemaet.

Udbyttet vurderer vi alle tre på en 10-skala til at være 10.

Vi har alle tre haft kontakt med elevcoachen, hvor vi har fået en hel del støtte til at få selvdisciplin og mødedisciplin, hvilket har betydet, at vores indstilling er totalt vendt rundt. Vi er alle nu velmotiverede og velfungerende og er indstillede på at fuldføre autouddannelsen (for tos vedkommende), mens den tredje af os påtænker at starte på gymnasiet efter sommerferien.

Vi vurderer samarbejdet med elevcoachen som værende meget betydningsfuldt for vores motivation og indstilling til uddannelsen - på en skala fra 1-10, vil vi alle tre vurdere det til et 10-tal.

Vi er vendt helt rundt og har fået en fornuftig dagsrytme. Vi har ikke lektier, har kun haft det en enkelt gang. Hvis coachen ikke havde været der, var to droppet ud, en tredje var fortsat, men på lavt blus.

Vi oplever ikke, at skolens øvrige personale eller vores holdkammerater har nogen form for negativ indstilling til det, at vi bruger elevcoach/psykolog. Tværtimod er der god opbakning til det og et godt samarbejde mellem de forskellige personalegrupper, der er ansat til at støtte os i vores uddannelsesforløb. Der kunne være lidt negative holdninger $i$ starten, men det har helt fortaget sig.

Nu fungerer klassen rigtig godt - selv om vi er de eneste piger $i$ klassen. Vi arbejder sammen på kryds og tværs, og en enkelt af os arbejder helst alene. Drengene ved lidt mere og det er en god kombination af drenge og piger. Dette fortsætter vi med resten af grundforløbet. 
Vores familier bakker os op og er glade for at det går så godt nu. Vi taler meget om vores uddannelsesforløb og de respekterer de beslutninger, vi tager. Mht. psykologstøtten får vi også opbakning fra familierne.

Vi kan ikke få øje på nogen forbedringsmuligheder: der er ikke noget, der kan forbedres ved coach-og psykologordningen. Det er indrettet helt, som det skal være.

Hvis vores motivation dykker, vil vi først snakke med hinanden om det og ellers snakke med coachen og psykologen. Hvis vi skal "brokke os" over hinanden, går vi til psykologen!

Vi bliver af og til spurgt af andre elever, hvordan det er at gå til psykolog, og så forklarer vi, hvordan det fungerer. Drengene har nok sværest ved at indrømme, at de har behov for hjælp, pigerne er ikke så stolte.

Vores oplevelse i undervisningen er ofte, at det kan være svært at være med i det tempo, lærerne sætter. De har ofte en meget stram lektionsplan - især i teoritimerne, og det kan være svært at følge med og få stillet de spørgsmål, der er behov for at stille. Lærerne oplever vi som ret fagligt orienterede og lidt svære at få en personlig/empatisk relation til. Der er nogle af lærerne, der har den empati og forståelse for vores situation, der gør, at vi kan opleve relationen som tryg og motiverende, men der er også nogle, der har den modsatte virkning på os. Selv om vi påtaler, at tempoet er for højt, tager lærerne ikke højde for det.

Vi har en "bedstefar" $i$ afdelingen, og han har en helt anden tilgang til undervisningen. Han er meget nem at kommunikere med og rolig i sin fremtræden, men har samtidig et stort fagligt overskud. Vi ville ønske, at alle lærere kunne være ligesom ham. Den empati og forståelse han har, bevirker, at vi helst går til ham, hvis der er noget, vi ikke forstår eller skal have forklaret en ekstra gang. Eller også burde "bedstefar" være i værkstedet, når der er teori. Han fungerer bedre læringsmæssigt end lærerne - man kan spørge ham ti gange uden at han bliver sur eller irriteret.

Vi har alle tre deltaget i samtaler med psykologen på individuel basis og har oplevet dette som meget positivt. Vi har fået hjælp til løsning af personlige problemer og til at få vendt forskellige livssituationer, når tingene har været svære. Det er en meget stor fordel at kunne få lejlighed til at vende tingene med en, der kan se det hele ude fra og kan give nye handlemuligheder, når tingene går $i$ hårdknude. Ofte handler det om konflikter $i$ elevgruppen, hvor vi skal have hjælp til at takle konflikter eller måske blot have et nyt synspunkt på, hvordan man finder inspiration til at fortsætte uddannelsen.

Man kan altid få gode råd til, hvordan man kan gøre tingene bedre eller ændre på vores interne kommunikation i gruppen. Vi har som regel faste ugentlige aftaler, hvis der er behov.

Vi vurderer alle tre, at hjælpen ligger på en 10'er på en 10-skala. Der er altid en god stemning i lokalet og man får en fin hjælp til at lose sine problemer i en god, konstruktiv atmosfære. Psykologen er rigtig god til at sætte sig ind i en anden persons situation, er meget empatisk, og aldrig fordømmende eller nedladende $i$ sin måde at behandle os på.

Vi har hver især nogle personlige udfordringer:

A. Jeg har ADHD og får hjælp til at tænke konstruktivt om dette problem, i stedet for at tænke negativt om det. Det har hjulpet.

B. Jeg har været nervøs for at komme i gang med forløbet her og troede ikke på mig selv - det fik jeg hjælp til at håndtere via nogle værktøjer.

C. Jeg har talt om personlige problemer, hvor jeg har fået nye måder at tænke over problemerne på. 
Vi får nogle værktøjer til at tænke over hvordan vi skal agere i vanskelige situationer - og det er værktøjer, vi trækker på i det daglige på skolen.

Det er meget vigtigt, at denne mulighed findes - hvis den ikke fandtes, ville vi alle tre være ude af uddannelsen og vi ville ikke vide, hvad situationen for os så ville være. Vi har haft en fast aftale om samtaler med psykologen.

Det er ikke umiddelbart muligt for os at pege på forbedringsmuligheder i de ordninger, vi har gjort brug af. De har fungeret optimalt for os og er fleksible og indrettet, så vi kan bruge dem, som vi gerne vil. Det kan ikke gøres bedre.

Hvis coachen og psykologen ikke var her, ville vi alle tre stoppe i uddannelsen - det må de ikke spare på, så kan vi ikke gennemføre uddannelsen. Hvis man har en dårlig dag, er det nødvendigt at skulle have hjælp. Det er deres skyld, at hverdagen er så god nu. De gor rigtig meget.

Vi var ikke kommet igennem grundforløbet uden deres støtte. Det giver ro at vide, de er der, og man føler at man kommer og snakker med sin bedste ven. De sætter sig virkelig ind $i$ situationen og prøver at forstå.

Psykologen kunne lære lærerne meget omkring empati. Lærerne burde være mere menneskelige. De kunne lære at tackle svære situationer - at behandle os som ligestillede.

Bedstefar er et godt forbillede. Vi ville ikke bryde os om en IT-ordning (digitaliseret vejledning/rådgivning) - det er den personlige kontakt, der er afgørende. Pengene er givet godt ud ved at fortsætte på denne måde. Det har effekt, og vi har fået lyst til at fortsætte på uddannelsen.

Vi er alle tre meget klare i holdningen til disse ordninger - de bor fortsætte i den form de har, for ellers vil mange elever ganske enkelt opgive deres uddannelser og falde fra.

Det opleves som en meget stor tryghed at have sådanne støttefunktioner i skolemiljøet, også selv om opbakningen fra vores familier er der, men tanken om, at man altid kan søge personlig hjælp og støtte, er en meget stor motivationsfaktor i dagligdagen.

\section{Interviews med elever i den individuelle ordning}

\section{Elev A}

Jeg er på pause i mit uddannelsesforløb, da jeg er inde i en dårlig periode pga. depression. Jeg har en aftale om, at jeg kommer hver uge, men deltager på en flexordning. Hvis jeg har det sådan, at jeg ikke kan deltage, tager jeg en cykeltur i stedet eller gor noget aktivt, der løfter mit humør.

Jeg var oprindelig lærling på Grundfos (industritekniker), men fik det så dårligt at jeg måtte afbryde forløbet og har så en aftale om, at jeg kan komme tilbage, når jeg er klar igen. På Mercantec har jeg så en aftale med psykologen om at indgå i et samtaleforløb og derudover taler jeg med en psykiater.

Jeg oplever, at have fået en meget god støtte hos psykologen - det er meget professionelt og godt. Jeg får også en del praktisk støtte til at snakke med kommunen og ordne papirer osv., da jeg får sygedagpenge nu. Jeg forventer, denne ordning skal vare et års tid. 
Jeg har altid haft det samme uddannelsesmål, men har ind imellem provet lidt andet af fx mureruddannelsen. Men den var ikke lige noget for mig. Nu holder jeg fast $i$, at jeg skal gå industriteknikervejen.

Jeg har en ret fast aftale med psykologen - som regel fredag - hvor vi taler sammen enten ved møde eller over telefonen. Det er rart med en sådan fleksibilitet, jeg kan komme, når jeg har behov og kan aflyse, hvis jeg ikke har overskud til det. Det er rart at vide, at psykologen altid er der, og at man kan trække på de ressourcer. Jeg har nok været til samtale 10-15 gange.

Vi kender efterhånden hinanden godt og har et fint forhold. Jeg har brugt ordningen $i$ to omgange.

Jeg får den vigtige støtte, at psykologen kan forklare overfor kommunen, hvordan min situation er, og hjælpe mig med papirarbejdet fx i forhold til sygedagpenge. Men jeg får også støtte til at tage andre initiativer, hvis jeg er "nede". Jeg løber fx en tur eller hører musik for at komme væk fra tunge tanker. Eller det kan handle om at tage kontakt med andre eller simpelthen ringe til psykologen, hvis det går helt $i$ sort. Jeg vurderer dette som en rigtig god støtte. Det giver mig nogle værktøjer, jeg kan bruge, når jeg har det svært.

Det kan også handle om at formulere andre tanker om situationen - skrive dem ned på et stykke papir og reflektere over, hvad der kan gøres. Positive tanker som "adspredelse". Jeg har ellers bare lukket mig inde og ventet på, at de negative tanker skulle forsvinde. Jeg har gået til noget idræt, men er stoppet. Jeg overvejer at finde noget nyt. Måske bueskydning.

Hvis psykologordningen ikke havde været der, ved jeg ikke, hvor jeg ville være - det tor jeg ikke tænke på. Jeg var nok droppet ud! Det har virkelig hjulpet mig.

På en skala fra 1-10 ville jeg vurdere det til 10, den hjælp jeg har fået.

På skolen oplever jeg opbakning til, at jeg går til psykolog. Der er ingen der er negative overfor det. Både lærere, ledere og elever har været positive. Lærerne ville slå ned på det, hvis nogen var negative omkring det.

Vi arbejder både i grupper og enkeltvis - lige nu foretrækker jeg at arbejde alene, da jeg ikke har det så godt. Der er en enkelt mere, der bruger ordningen, så vidt jeg ved. Jeg kan godt snakke fint med mine lærere på tomandshånd, de er som hovedregel meget forstående. Fra den kant har jeg fået en god støtte. Det er en god ordning - den optimale - jeg har fået tilbudt.

Jeg kan ikke få øje på forbedringsmuligheder mht. ordningen. Det er jo begrænset hvor meget andre kan gøre. Det har været over forventning!

Jeg bruger ikke kontaktlærer og coach så meget. Mest til møder med kommunen. Jeg har talt lidt med "bedstefar". Det primære har været psykologen. Familien bakker mig helt op omkring dette.

Jeg ser fremad og er fortrostningsfuld. Jeg kan kun anbefale at en sådan ordning skal fortsætte. 


\section{Elev B}

Jeg har gået til psykolog i over et år, og det var en overvindelse at komme i gang. Jeg vil helst løse mine problemer selv, men pludselig blev det hele for meget for mig, og jeg fik stress og overvejede at droppe ud. Jeg fik noget rum og skulle også løse nogle meget personlige problemer.

Mit hovedproblem var nok, at jeg ikke kunne prioritere, så jeg fik en kalender, der hjalp mig med at få struktur i min dagligdag. Jeg skrev ned, hvad jeg skulle lave på præcise tidspunkter. Det har hjulpet mig rigtig meget. Og jeg har lært metoder til at afstresse - det har hjulpet rigtig meget. Jeg lærte fx noget "Mindfulness", det er såre simpelt, men det virker! Jeg bruger det stadigvæk.

Jeg lærte at håndtere min stress - lærte at lave ændringer i mit liv. Man lytter meget, når det er en psykolog. Hun er god til at lytte sig ind til en og sætte ting i perspektiv. Det er dejligt at kunne komme ned og få renset ud.

Jeg havde også et stofmisbrug, jeg røg noget, jeg ikke skulle ryge - og her fik jeg også hjælp og redskaber. Der var ikke noget valg og jeg lærte at håndtere dette også.

Hvis muligheden ikke havde været der, var jeg helt sikkert droppet ud af uddannelsen. Jeg troede ikke, hun kunne hjælpe mig, men det kunne hun! Mine problemer har gået ud over skolen, men jeg er blevet skubbet på rette vej.

Jeg var meget reflekterende og havde for mange tanker, og jeg kunne ikke styre tankerne. Mange overflødige tanker - hvad skulle jeg gøre? Jeg lærte at løse problemerne $i$ den rigtige rækkefølge og løse dem, der KAN løses. Det er godt at få erfaringer at lære af - og det har jeg fået. Og de gode skub har hjulpet mig.

Jeg har ingenting negativt at sige - alt har været fint.

Der er nogen der ved jeg har gået der, men jeg har ikke fået negativ respons på det fra kammeraterne. Mit udbytte har været meget stort, og jeg vil klart anbefale at ordningen fortsætter som den er.

Det har også været fint, at kunne skrive til psykologen på SMS også. Jeg har ikke rigtig nogen kritik af ordningen. Det har hjulpet mig. Og risikoen for depression er forduftet. Hvis jeg havde sygemeldt mig på lægens råd, var jeg røget ud af uddannelsen. Nu gik jeg den anden vej-og det var det rigtige.

Der er ingen argumenter for at lukke en sådan ordning.

Ordningen er et fint og fleksibelt tilbud, men måske ville det være fint med et styrket samspil mellem lærere og psykolog. 


\section{Elev C}

Jeg opsøgte psykologen, fordi jeg havde præstationsangst i forbindelse med eksaminer. Jeg har altid haft selvtillidsproblemer - ville gerne være den bedste $i$ alt. Jeg har haft 4-5 samtaler, i starten en gang om ugen, nu med lidt storre mellemrum. Det er rart at kunne komme og tale om problemer - jeg havde nogle problemer i forbindelse med noget teambuilding. Derfor startede jeg hos psykologen.

Jeg får nogle værktøjer i form af at kunne sige noget til mig selv - ikke tænke på, hvad andre siger om mig. Det har hjulpet mig meget. Nu tager jeg en eksamen ad gangen og tager det stille og roligt. Min lærer har været god til at spørge ind til hvordan det går med psykologen.

Det er godt at få luftet tankerne og få frustrationerne ud. Det er et godt fortroligt rum. Klassemiljøet kan godt blive lidt for tæt og sammenspist - så er det rart at komme til psykologen. Kammeraterne ved godt, jeg går der, og de har det fint nok med det. Ingen negative reaktioner.

Flere kunne sikkert godt have brug for det. Jeg har taget mod til mig i flere år. Mange har nok nogle fordomme om at gå til psykolog, men det er helt ubegrundet.

Der findes grupper mod eksamensangst, men jeg har ikke deltaget.

Hvis ikke jeg havde fået hjælp, havde jeg kørt mig selv ned og var måske droppet ud. Jeg ville i hvert fald ikke kunne præstere på samme niveau uden hjælp. Det har virkelig hjulpet mig rigtig meget. Som det har været, har det været rigtig fint. Jeg har selv skulle tage aktion, og det er fint. Jeg har fået snakket ud om det, jeg har brug for. Det er fleksibelt og individuelt og det er godt. Jeg har ingen kritik af ordningen, og jeg overvejer ikke at sige fra nu.

Måske er beliggenheden et problem - det kan være ubehageligt at sidde på gangen og blive peget ud som en, der skal til psykolog.

Digital kommunikation med psykologen er ikke vejen frem, men det er godt med tilbagemeldingsmulighed via SMS. For mig er det godt, hun er en kvinde. Drengene bruger typisk ikke ordningen, de er nok for stolte til det.

\section{Sammenfatning}

De gennemførte elevinterviews viser samstemmende, at eleverne vurderer psykologordningen meget positivt, idet de fremhæver et udbytte af samtalerne, der sætter dem i stand at tackle de problemstillinger, der blokerer for deres aktive deltagelse i uddannelse.

Eleverne siger - uden undtagelse - at de sandsynligvis ville være frafaldet deres uddannelse, hvis ordningen ikke havde eksisteret. Ordningen har på forskellig vis givet dem hjælp til at tackle større eller mindre problemer mht. manglende motivation, mangel på struktur, eksamens- og præstationsangst samt depressive tilstande.

Direkte adspurgt giver eleverne udtryk for, at de ikke kan se oplagte udviklings- eller forbedringsmuligheder, hvad ordningens organisering angår. De oplever ordningen som fleksibel, nem at opsøge og vurderer, at der ydes hjælp af høj professionel standard, når de opsøger psykologen. 
Eneste kritiske kommentar vedrører ordningens praktiske indretning, idet en enkelt elev bemærker, at det kan føles som at blive "udstillet", når man venter på at skulle til samtale på det kontor, der er beliggende på auto-gangen.

\subsection{Hvad siger forældrene om ordningen?}

Der er gennemført et telefoninterview med en forælder til en elev, der har brugt psykologordningen i forbindelse med oplevede personlige problemer i sit uddannelsesforløb.

\section{Interviewudsagn}

Min søn har brugt ordningen, og det har virkelig gjort en forskel for ham!

Han har brugt ordningen over et langt forløb, med nogle indlagte pauser, og så har han kommet tilbage igen, når han har haft behov for det.

Det har fungeret rigtig fint, og der kan ikke siges noget som helst negativt om det. Det har været ret afgørende for hans udvikling, at muligheden for psykologstøtte har været der. Så ingen tvivl om, at det har været positivt og succesfuldt.

Min søn har stor tillid til ordningen, og det har fungeret som en god livline for ham og har aflastet familien, som nok kan støtte ham, men anden støtte ude fra er også vigtig.

Min vurdering er, at ordningen er meget fleksibel, og at man har mulighed for at bruge den akut, og det er en indretning, der har passet godt til vores behov. Han har kunnet bruge psykologen i situationer, hvor der lige var noget, han havde behov for at få svar på "her-og-nu", og det har klart været en fordel for ham. Jeg har været med ham en enkelt gang.

Han var lidt skeptisk i starten overfor at skulle bruge psykologordningen, om det nu var "noget", men har efterhånden oplevet at få så meget udbytte af sine besøg, at han generelt har oplevet en meget vigtig stotte hos psykologen.

For os er der derfor ingen tvivl om, at skulle behovet vise sig igen, vil vi ikke tøve med at bruge ordningen. Jeg kan kun anbefale, at der bliver ved med at være den mulighed for unge mennesker, fordi der hurtigt kan opstå situationer, hvor behovet for psykologisk støtte er til stede.

Det er vigtigt, at skoler kan give disse tilbud, for det kan være svært selv at finde psykologer der har indsigten i unge menneskers liv og færden $i$ en uddannelsessammenhæng. Det giver en særlig kvalitet, når der er tale om en psykolog, der dagligt arbejder med unge og deres udfordringer. Ellers er der jo typisk tale om psykologer, der arbejder med voksne og deres problemstillinger.

Her handler det om unge, der er på vej til at blive voksne, og denne livsalder og uddannelsessituation kræver en særlig ekspertise, som vi altså har mødt her.

Summa summarum har erfaringen været, at oplevelsen har været rigtig god med ordningen både mht. den praktiske organisering og det indholdsmæssige. 


\section{Sammenfatning}

Den interviewede forælder udtrykker den klare holdning, at psykologordningen er en velfungerende og fleksibel indrettet støtteforanstaltning af høj faglig kvalitet. Især fremhæves den kvalitet ved ordningen, at elever kan få hjælp nu-og-her, og at psykologen - qua sin daglige involvering i skolens uddannelsesmiljø - har en indsigt og derfor kan formilde en støtte, man ikke ville kunne finde tilsvarende andre steder.

\subsection{Hvad siger lærerne om ordningen?}

Der er gennemført et fokusgruppeinterview med fire lærere, repræsenterende forskellige afdelinger på skolen.

\section{Interviewudsagn}

Ordningen er to-sidet, dels en hjælp for eleven, hvor eleven kan få hjælp med noget, lærerne ikke kan hjælpe med, dels en hjælp for lærerne, der kan få inspiration til at tilrettelægge den daglige undervisning, så den er bedst mulig. Hvad kan motivere den enkelte elev, og hvordan griber vi det an?

Vi er typisk håndværkere, der ofte kommer til kort overfor de elever, der har specielle problemer eller udfordringer. Vi har deltaget i nogle kurser, men savner ofte værktøjer til at håndtere vanskelige situationer i undervisningen. Så den pædagogiske støtte fra psykologen er en vigtig ting.

Hvis vi vil udvikle på ordningen, bør vi især se på de lange ferier (jul, sommerferie mv.), hvor vi ofte oplever, at elever får problemer og dropper ud. I dagligdagen har vi rimeligt styr på eleverne, men i disse ferieperioder har vi ikke styr på eleverne. Når eleverne ikke har et sted at henvende sig, risikerer vi, at de er for meget overladt til sig selv og derfor udvikler "risikoadfærd". Det er ofte som om vi skruer tiden to måneder tilbage i ferierne. Jo længere ferie, desto større problemer oplever vi. Dette må vi kunne forbedre ved et oget beredskab - måske hos psykologen. Vi bliver ofte kontaktet af elever i aftentimerne, der har brug for hjælp og det er os der henviser til psykologen, hvis problemerne er betydelige. Måske kunne en form for ferielejr eller sommerskole i regi af Pyramiden være vejen frem?

Beredskabet lige nu er primært et "frivilligt" beredskab blandt lærerne (os), men den dag dette ikke kan fungere længere, har vi et stort problem og ingenting at byde på. Så skal eleverne selv opsøge en psykolog, og det vil mange afholde sig fra at gøre. Så der burde være et mere officielt ferieberedskab, hvis vi ikke skal tabe mange elever. Det frivillige er fint, men kan ikke bære igennem. Måske burde der være et netværk, hvor lærere, coaches og psykolog i fællesskab løftede opgave. Det vil være meget værdifuldt for skolen.

I virkeligheden har vi behov for flere ressourcer - måske to fuldtidsansatte psykologer.

Eleverne får vigtige redskaber til at tackle problemer hos psykologen, og det opleves som en meget værdifuld støtte, der ikke kan undværes. Vores kompetencer rækker typisk ikke til at kunne give den hjælp, som en psykolog kan give. Visse ting kan vi godt hjælpe med til, men i svære situationer er psykologen uundværlig. Eleverne kan enten selv opsøge psykologen eller blive henvist af os eller elevcoachen. 
Som ordningen er nu, er den god og fleksibel. Mange af vores elever har været igennem andre former for stotteforanstaltninger og kan have modstand mod at skulle til psykolog, men når vi forklarer om ordningen, giver de ofte accept på at deltage.

De gamle tekniskskolelærere kan have en tilbøjelighed til at opfatte elevproblemer som "unødvendig støj" og bortvise eleverne - sådan er der mange, der tænker. Eleverne er en meget blandet gruppe, og man skal magte at differentiere meget i sin tilgang til dem også på et menneskeligt plan. Her er psykologen en vigtig ressource for os som sparringspartner. Psykologen kommer ofte forbi for at drøfte, hvordan det går, og det giver mulighed for gode drøftelser af vores udfordringer på en nærværende måde.

Hvis tiden var til det, kunne vi ønske, at psykologen kom lidt mere forbi og hilste på, så alle lærer hende at kende, men vi ved godt, at hun har ret travlt i det daglige. Som regel inviterer vi dem over, når vi starter et nyt hold op, så de lige kan præsentere sig - både psykolog og elevcoaches. Alle lærere kender ordningen - det er vores klare vurdering. Måske har nogle lærere den opfattelse, at på hovedforløbet bør man ikke have behov for psykologstøtte - der skal man bare kunne køre derudaf.

Det er fint som lærere at have flere henvisningsmuligheder - vi kan både trække på elevcoaches og psykolog og det giver en god spændvidde i vores handlingsmuligheder. Vi lærer at vurdere situationerne og finde den rette henvisningsmulighed.

I gennemsnit henviser vi nok en 2-3 elever fra hvert 10-ugers hold til psykolog, men det kan variere meget. Især $i$ august er presset stort, men det aftager så lidt hen i skoleåret. Det kan også handle om enlige forsørgere eller misbrugsproblemer, det behøver ikke være en diagnose. I disse sager kommer vi som lærere til kort, og her må vi vælge at stå af.

Vi skal være meget bevidste om, som lærere, hvornår vi faktisk KAN hjælpe med de kompetencer, vi nu har, og hvornår vi skal afholde os fra at intervenere fx i forbindelse med helbredsproblemer. Psykologen er uddannet til at finde de rette redskaber i den givne situation, det er vi jo ikke. Det handler om professionel indsigt.

Hvis psykologen ikke var her, ville eleverne være helt overladt til de lærere, der frivilligt ville stille sig til rådighed - også uden for skoletimerne, og det ville være en uholdbar situation. De udsatte elever er ofte uden et fungerende familienetværk, så de har ikke andre steder at søge hjælp.

Mange elever skal have hjælp til at danne sociale netværk - de kan ikke af sig selv og bliver passive og opgivende. Det skal tænkes ind i vores undervisning. Måske skulle skolen tænke mere $i$ at integrere sports- og fritidslivet i sin dagligdag, så eleverne kunne støttes i at få interesser og etablere netværk. Det ville være et klart fremskridt. Mange bor på skolehjem, men skolehjemmet kunne måske også byde på flere aktiviteter. Der er ingen, der sætter ting i gang der. Der mangler en social dimension.

Det er vigtigt med en god holdstart, og her har psykologen ofte kunnet bidrage med bistand til at få nye hold til at fungere godt. Problemet er blot, at det som regel kun er nye hold efter sommerferien, der fär det tilbud. De andre hold sker der ingen ting for. Man burde arrangere noget, så gamle og nye elever kom tættere på hinanden og dermed danne flere netværk.

Der har været gennemført "relationsforløb" for nye elever, men det har primært været coachene der har stået for det - det havde været fint at have psykologen inde over det, men det handler jo nok om prioritering? Det var rigtig godt som sammenrystning og "lære-at-kende-forløb" er en meget givende ting. De tre dage gav rigtig meget udbytte, og det kan sikkert videreudvikles via psykologens deltagelse. 
Generelt ville det være fint, hvis psykologen kunne være mere til stede på de enkelte afdelinger - bare hilse på og give sig til kende, så eleverne bliver trygge ved hende og afdramatisere det hele lidt. Vise, hvor mange muligheder der er.

Elevernes udsagn om, at de kan føle sig udstillet, når de sidder på gangen og venter på en psykologsamtale er forståeligt, men ingen elever har sagt lignende til os. Der er stor forskel på, hvor anonym man kan være de to steder, der bruges til samtaler, og det bør man måske tænke over som skole.

Hvis ordningen ikke var der, ville det gøre mange ting betydelig sværere for os, og det ville være en katastrofe for mange elever. Det er en betryggelse i dagligdagen, at der er en livline, vi kan bruge og få professionel bistand til problemløsning i svære situationer.

Skolen har med sin pædagogiske model en unik støtteforanstaltning, og det ville være meget svært at leve uden. Der er ingen tvivl om, at det medvirker til at reducere frafaldet. Vi kan ikke sætte tal på, men der er nok ingen tvivl om, at det samlet set er en god "forretning".

Psykologen sparrer også med coachene og kontaktlærerne - det er også en værdifuld side af funktionen. Tilsvarende sparring finder sted mellem eksterne behandlere og psykologen - den sparring kan vi ikke udøve på samme kvalificerede vis. Her får man et kvalificeret bud på, hvornår udsatte elever er parate til at komme tilbage til indlæring - en vurdering, vi ikke umiddelbart kan foretage.

Vi har flere eksempler på, at elever, vil ellers havde opgivet, er blomstret op efter at have fået psykologbistand - det er meget positivt at opleve.

Det er ofte de menneskelige eller sociale problemstillinger der stiller sig i vejen for det faglige - her ligger en udfordring vi skal lofte sammen. Eleverne har svært ved at investere sig selv i relationer og skal lære det hos os. Det er det, der er det svære at arbejde med, og det er her, en psykolog kan hjælpe os på vej.

Psykologen kunne understøtte hele lærerstaben $i$ at have et mere personligt/socialt perspektiv på læringen, i stedet for at fokusere så meget på det faglige, som mange lærere kan være tilbøjelige til. Hovedforløbslærere kan savne forståelse for det, vi arbejder med på grundforløbet, og oplever det som uvedkommende.

Summa summarum: Pyramiden og psykologen er undværlige som forudsætning for at skolen skal lykkes med sin indsats.

\section{Sammenfatning}

De interviewede lærere oplever psykologordningen som på den ene side en vigtig aflastningsmulighed i tilfælde af akutte problemer hos eleverne, på den anden side som en mulighed for sparring og inspiration, der kan vise dem nye veje i det pædagogiske arbejde.

Lærerne peger på et centralt problem, nemlig spørgsmålet om, at ferieperioder ofte resulterer $\mathrm{i}$, at elever udvikler risikoadfærd og af den årsag kan blive frafaldstruede. Lærerne foreslår, at skolen organiserer et støttesystem i disse perioder, så eleverne ikke er overladt til sig selv.

Vurderingen af ordningen blandt lærerne er, at ordningen er uhyre værdifuld (sammen med de øvrige elementer i Pyramiden) som frafaldsværn, idet eleverne kan få hurtig, 
smidig og professionel hjælp i svære situationer - en hjælp, lærerne ikke selv føler sig i stand til at give og også helst afstår fra, da de mangler den professionelle indsigt, der skal til.

Lærerne ser en udviklingsmulighed i at knytte psykologen tættere til lærergruppen, dels i form af hilse-på-møder af mere uformel karakter, dels i form af øget kursusaktivitet om relevante emner og endelig som en ressourceperson, der kan understøtte lærerne i at tænke undervisningen mere "helhedsorienteret", dvs. ikke primært fagligt, men netop adresserende elevernes personlige, sociale og menneskelige potentialer.

\subsection{Hvad siger mentorerne, kontaktlærerne og studievejlederne om ordningen?}

Der er gennemført et fokusgruppeinterview med fem personer fra denne personalegruppe repræsenterende forskellige afdelinger på skolen.

\section{Interviewudsagn}

Det er vigtigt at have en psykolog "i huset" man kan sparre med, når man har vejledende funktioner som mentor/kontaktlærer eller studievejleder. Her har man muligheden for at drøfte elever, og man kan hente ny energi til sit arbejde, så man undgår udbrændthed.

Enkelte har faste samtaler med psykologen, men for flertallets vedkommende er det mere ad-hoc-præget. Psykologen kommer tit forbi på lærerværelset, men ofte er det os der henvender os til psykologen for en drøftelse af problemstillinger.

Psykologen har to vigtige funktioner: dels den hjælp der ydes til eleverne, dels den aflastning af det arbejde, vi udfører som støttepersoner. Vi står ofte $i$ situationer, hvor der skal handles hurtigt, og hvor vi måske ikke har den indsigt, der skal til for at handle rigtigt. Her er det meget værdifuldt at have en henvisningsmulighed, så man ikke blot skal sende elever hjem. Det ville være forfærdeligt.

Vi plejer at præsentere psykologen som en "værktøjskasse", man kan bruge, hvis noget står i vejen for indlæring. Det er en fantastisk mulighed at have. Der kan også være alvorlige akutsager, hvor det er vigtigt at handle professionelt korrekt (fx selvmordstruede elever) - her er det et privilegium at have en psykolog til rådighed. Det giver en enorm tryghed.

Det kan også handle om bistand i sager med eksterne aktører, hvor det er vigtigt at kunne få bistand til at afkode diagnoser el. lign. Eller det kan handle om, at man som studievejleder kan være forsigtig med at "rippe op" i ting, som man ikke kan overskue konsekvenserne af - her kan psykologen langt bedre agere. Her ved man, tingene bliver lukket på en ordentlig måde.

Ligeledes er det vigtigt i forhold til forældrene i optagelsessituationer, hvis fx eleven har en diagnose, kan man berolige forældrene med at man har Pyramiden med forskellige grader af professionel hjælp, man kan trække på, herunder psykologen.

Det er med tiden blevet mere anerkendt, at skolen har en psykolog - dette har fx forældrene i stigende grad vist forståelse for. Tidligere blev man opfattet som "gal", hvis man havde behov for psykologbistand - sådan er det ikke længere. De unge er også blevet 
mere åbne overfor at kunne få denne type hjæ/p - dette gælder også drengene, der bedre kan tale om følelser.

Behovene for bistand er meget forskellig fra hold til hold, og også afhængigt af om vi taler om handelsskolen eller teknisk skole, ligesom det varierer over året. Ligeledes spiller alderssammensætningen en vigtig rolle.

Det ville være meget svært at undvære en psykolog på skolen - det er blevet en indarbejdet del af skolens kultur, at vi har denne ressource til rådighed. Både i forhold til eleverne og i forhold til vores egen sparring.

Alternativt skulle vi sende eleverne ud af huset til ekstern støtte, men der støder vi ind $i$ de lange ventelister, der ofte er hos psykologer "ude i byen". Det er en meget hurtigt fungerende og fleksibel ordning, der gor det meget overskueligt for eleverne at komme $i$ gang, hvis de har behov. Ofte er det blot et par samtaler, der skal til, før eleverne er på sporet igen. Det kan blot handle om at blive bekræftet $i$, at man er OK normal.

Det ville sikkert også være mere bekosteligt, hvis vi skulle tilkøbe bistand eksternt. Og ordningen bliver ikke misbrugt, så vidt vi kan vurdere det.

Det er en meget fleksibel indretning, ordningen har - og vi møder altid stor velvillighed, når vi henvender os. Strukturen i Pyramiden er velbeskrevet og klar, så alle ved, hvad de skal gøre, og psykologen fungerer som sidste led $i$ kæden. Der er et fint og konstruktivt samspil mellem de forskellige led i Pyramidens "kæde".

Måske kunne psykologens kompetencer anvendes på nye felter: supervision af lærere kunne være et oplagt område at gå ind i. Lærerne er med tiden blevet mere åbne mht. at rådføre sig med og få hjælp fra psykologen, hvilket åbner mulighed for et tættere samspil mellem lærergruppen og psykologen omkring den pædagogiske praksis. Nogle problemer bliver af samme årsag løst tættere på.

En anden udviklingsmulighed for ordningen kunne være, at psykologen holdt kurser $i$ de typiske diagnoseformer: $A D H D$, autisme etc. Vi får flere diagnoseelever, og det ville være fint at blive klædt bedre på. Det kunne handle om samtaletræning på et helt elementært plan. Klasselærere kunne have god gavn at kende mere til elevers udfordringer på dette område. Det har vist været planlagt, men har ligget lidt stille en periode.

Det kunne fx organiseres som teammøder $i$ hver enkelt afdeling, hvor de centrale aktører $i$ afdelingen blev klædt på til at møde disse udfordringer, som nok forstærkes af reformens forandringer. Men det kan være svært at samle lærere til denne type arrangementer, så måske burde det være obligatorisk for klasselærere at deltage $i$.

Måske kunne hjemmesiden erfaringscenter.dk styrkes og vi kunne som lærere bruge den mere aktivt. Her kunne lægges flere informationer, men det er meget tidskrævende i forhold til udbyttet.

Der er så mange tidskrævende projekter på skolen, så det kan være svært at involvere sig i nye vidensfelter. Der er tit for mange bolde i luften.

Psykologen burde være en fast finansieret ordning, der ikke nødvendigvis skulle hænge sammen med andre gøremål: kurser, hjemmeside etc. Måske burde man sætte det på finansloven.

Det giver den tryghed, der er nødvendig, men vi bør selvfølgelig arbejde på at reducere behovet for psykologer. Alle vores arbejdsgange ville blive mere besværlige, og frafaldet ville utvivlsomt vokse, hvis vi ikke havde psykologen. 
Den vigtigste funktion er elevsamtalerne, men klasselærerne bør støttes mere i deres arbejde, ikke mindst fordi der er så mange nye her. Det er hele Pyramide-organiseringen, der er vigtig som tryghedsfaktor. Der kan være forvirring om rollerne, men psykologens rolle står klar.

Pyramiden er en genial konstruktion, men den kan give forvirring udadtil pga. de mange roller, men grundlæggende set fungerer det godt. Psykologerne kunne møde op et kvarter før start på lærermøder og give korte introduktioner til deres arbejde eller tage specifikke problemstillinger op. Så kunne klasselærerne fordybe sig mere med psykologen.

Trivsel er et emne der kunne bearbejdes sammen med psykologerne - der er meget fokus på det, men vi skal passe på, det ikke kun bliver faglighed. Her kunne psykologen have en vigtig rolle.

Psykologen holder åbne kurser (fx eksamensangst) for alle elever på skolehjemmet. Hvilket også er meget gavnligt. Noget er forsøg, og ikke alt kan fungere optimalt. Det kan handle om generthed, her kunne psykologen også have en rolle.

Mht. oplæring af nye lærere er det typisk en ældre kollega der er vejleder, og det fungerer meget forskelligt. Tilbud om støtte her kunne også være relevant, især for lærere uden undervisningserfaring. Det er sjældent, men der er tilfælde, hvor ubehagelige oplevelser $i$ undervisningen kunne vendes med psykologen.

Der kan være et problem i, at elever skal udstilles på vej til psykolog-det er en helt håbløs ordning, og den bør ændres. Der skal tænkes langt mere i nye løsninger her. Det burde være mere anonymt eller privat.

Hvis man ikke kan se værdien $i$ at medarbejdere trives bedre, når der er en psykolog $i$ huset, så er det helt uforståeligt. Man bør fortsætte en sådan ordning, der er ikke noget der taler imod det. Der kan og bor findes midler til at fortsætte ordningen, men der skal nok tænkes kreativt.

\section{Sammenfatning}

De interviewede oplever en stigende anerkendelse af ordningens værdi, såvel fra elevside som fra skolens ansatte og eksterne aktører. Ordningen vurderes som professionel og af høj faglig standard samt indrettet på en måde, der gør den let tilgængelig og fleksibel.

Der peges på de mange arbejdsfelter, der efterhånden har udviklet sig i og med, at ordningen har eksisteret i en årrække, og der udpeges også en del muligheder for udvikling af ordningen:

- Psykologen kan indgå mere i undervisningssupervision af lærere

- Der kan afholdes fagligt-psykologiske teammøder i afdelingerne

- Støtte til oplæring nye lærere

- Forbedring, dvs. større anonymisering, af adgang til samtaler

- Videreudvikling af hjemmesiden erfaringscenter.dk som formidlingskanal til lærerne

- Fokus på elevtrivsel i skolens dagligdag

Samlet set vurderes ordningen som værende "helt uundværlig" og ønsket om en fortsættelse af ordningen er stærkt. 


\subsection{Hvad siger UU om ordningen?}

Der er gennemført et telefoninterview med en vejleder fra UU med opgaver i forhold til Mercantec.

\section{Interviewudsagn}

Vi arbejder sammen med Mercantec på flere fronter, pt. gennem et projekt "Styrkelse af unges mentale sundhed", men kender også til psykologordningen. Det er Sundhedsstyrelsen og Psykiatrifonden, der har det overordnede ansvar for projektet. Det handler om at sætte ind overfor unge, der har mentale og sundhedsmæssige udfordringer - spotte og undervise eleverne.

Vi samarbejder med nøglepersoner på Mercantec (og SoSu) omkring dette og har derudover samarbejde med personalet i Pyramiden, herunder psykologen. Jeg har som vejleder haft direkte samarbejde med psykologen, når jeg har henvist unge til Mercantec, hvor behovet for psykologstøtte var til stede. Det handler om at involvere psykologen i forløb, hvor udsatte unge skal have bistand.

Min oplevelse er, at Pyramiden fungerer velstruktureret og klart, sådan at coaches og kontaktlærere afdækker behov og evt. henviser til psykolog. Tilsyneladende fungerer ordningen fint, vurderet på de tilbagemeldinger vi får, men det er meget svært at måle på effekten af ordningen som sådan. Der er mange faktorer, der spiller ind i forhold til frafald og fastholdelse, men det virker, som om der er godt styr på det hele.

Det er ikke alle vejledere hos os, der har et indgående kendskab til ordningen, men alle vejledere ved, at ordningen er der. Vi kan ikke udefra henvise til en psykolog, det skal ske internt, men i overgangsfasen kan dette dog godt finde sted, og her kunne kommunikationen godt forbedres. Vores oplevelse er, at de informationer vi giver til skolen, ikke videregives til de professionelle, der skal bruge dem i deres arbejde. Det er administrationen på Mercantec, der modtager oplysningerne, og som skal sende dem videre $i$ systemet. Her kunne kommunikationen blive bedre.

Vi savner tilbagemeldinger på, om og hvad der bliver iværksat på skolen. Mercantec kunne med fordel se på, hvordan den interne kommunikation fungerer og give feedback på, hvad vi som organisation kan gøre for at understøtte deres arbejde med fastholdelse.

Jobcenteret samarbejder med Mercantec i forbindelse med uddannelsespålæg - også her savner vi tilbagemeldinger på, om støtteforanstaltningerne bliver iværksat. Vi bruger selv gennemstromningsanalyser - noget lignende kunne Mercantec med fordel gøre. Det kunne nok være en rigtig god ide. Det forhindrer fejl og smidiggør systemet.

En gennemgang af arbejdsgangene ville være sundt, når det handler om overgangssituationen.

Der finder ingen formel evaluering sted af psykologens indsatser - det kender jeg ikke noget til, men det ville være relevant at sætte $i$ værk, så vi kunne få mere feedback på, hvordan det går med den enkelte unge.

Vi kunne lige sætte os ned og evaluere hele overgangssituationen sammen - det ville være yderst relevant.

Hvis ordningen ikke var der, ville mange ting blive vanskelige. Der er mange skrøbelige unge, der har brug for ordningen, men man burde arbejde mere med dens synlighed 
overfor de unge. Man burde sikre sig, at de unge har et godt kendskab til Pyramidendet er næppe noget problem for de professionelle. Det ville forbedre effekten af arbejdet. Der er mange unge, der har svært ved at rette henvendelse, og det ville styrke dem, hvis de fik et bedre kendskab til ordningen.

En bedre italesættelse og synliggørelse i form af skiltning kunne gøre ordningen til en fast del af skolens image - det ville være en fordel. Mit indtryk er, at mange elever ikke kender til ordningen. De skal spottes, før der sker noget.

Der er en stærk vilje til at møde de unge og et stort engagement, men effektivisering og synliggørelse kunne efter min vurdering give nogle gevinster. Det er en stor institution, hvor ting nødvendigvis skal samstemmes bedre.

De mange initiativer, der er i gang omkring trivsel, er et godt grundlag for at udvikle de unges overgangs- og fastholdelsesfærdigheder. Det giver relevante værktøjer at arbejde med.

\section{Sammenfatning}

UU har en oplevelse af psykologordningen som velfungerende og velstruktureret, men påpeger også, at man oplever visse problemer med ordningen, der især vedrører elever $\mathrm{i}$ overgang fra grundskole til erhvervsuddannelse. Der forekommer her situationer, hvor UU angiveligt beder Mercantec om psykologbistand til bestemt elever, men oplever, at dette ønske ikke videregives fra skolens administration til "rette vedkommende", typisk lærer eller kontaktlærer.

Der peges således på følgende forbedringsmuligheder:

- At der gennemføres en "gennemstrømningsanalyse", der kan vise, hvor kommunikation omkring elever med støttebehov KAN kikse

- At der følges bedre op på de elever, der modtager psykologbistand, og at der herefter gives feedback til UU om udfaldet heraf

- At skolen øger indsatsen for (fx via bedre skiltning), at eleverne kan få kendskab til ordningens eksistens, og dermed klædes bedre på til at egen drift at kunne bruge tilbuddet.

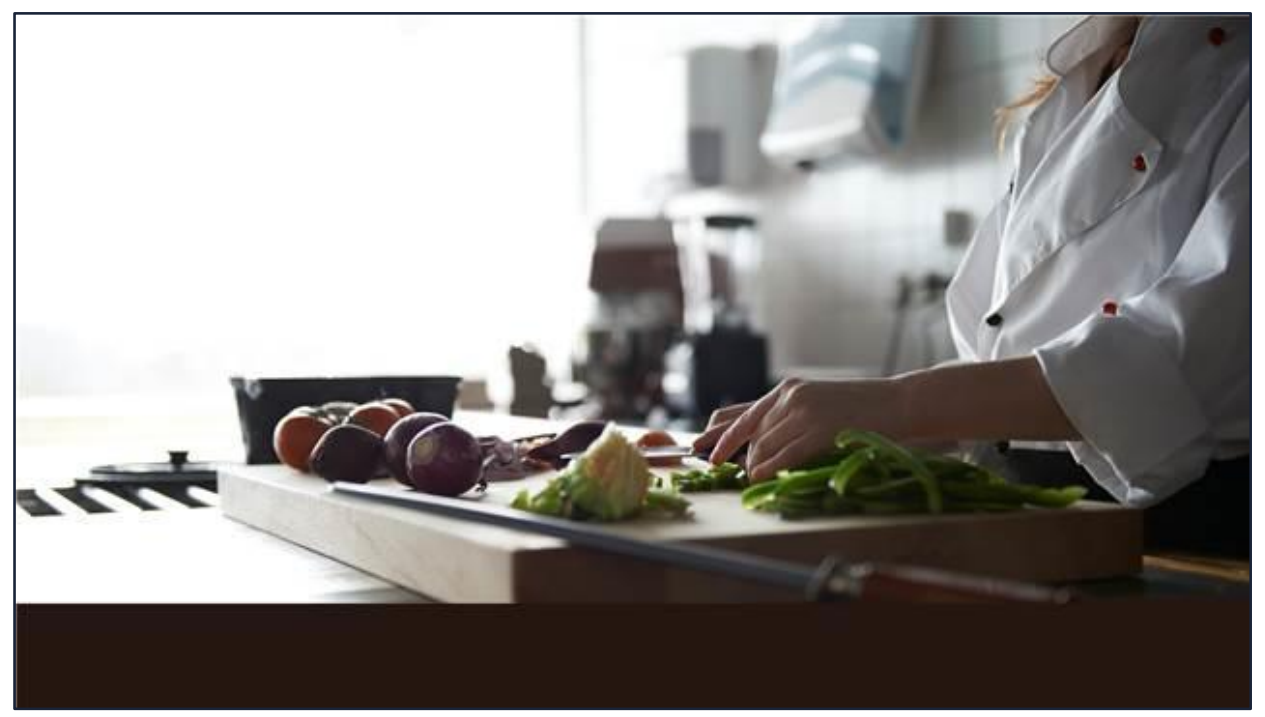




\subsection{Hvad siger projektkoordinatoren om ordningen?}

Der er gennemført et interview med projektkoordinatoren, der koordinerer arbejdet med ordningen.

\section{Interviewudsagn}

Set fra min position er det vanskeligt at bedømme indholdet i ordningen direkte, jeg ser den udefra som projektkoordinator.

Mht. kommunikationen med UU kunne man følge op på ordningen ved elevinterviews og afdække evt. svage punkter, som UU påpeger. Måske ønsker nogle elever "rent bord", når de starter på skolen her.

Der ligger ikke en egentlig arbejdsbeskrivelse for psykologen, men en kontrakt, og arbejdet baserer sig på tillidsforhold. Indholdet $i$ arbejdet udvikler sig lidt i spring og ikke efter en nøje aftale, og det er måske nok en svaghed ved ordningen, fordi skolen er $100 \%$ afhængig af psykologens indberetninger. Der er ikke indbygget kontrolmekanismer i ordningen.

Ordningen er bekostelig, og der skal nu findes midler til en fortsættelse af ordningen, hvilket er en udfordring for os som skole.

Vi har droftet placeringen af funktionen, og der er en erkendelse af, at det er vanskeligt både at være synlig og tilbyde eleverne den fornødne anonymitet. Dette kunne nok gøres smartere. Psykologens arbejdskontor er heller ikke indrettet optimalt - vi er i konstant bekneb for plads. Skal vi fortsætte ordningen, må der nok findes bedre rammer for psykologen.

Alle er indstillet på, at ordningen skal fortsætte, men der skal findes en finansieringsmodel. Spørgsmålet er, hvad den nye reform kommer til at betyde for miljøerne - det vil fremtiden vise. Måske vil reformen tage toppen af nogle problemer, men bestemt ikke fjerne dem helt.

Vi har kørt ordningen siden 2007 og kulturen har indstillet sig på, at vi har den facilitet. Efter min mening bør vi fortsætte ordningen, fordi den er helt nødvendig for skolen. Man kunne drømme om at få effektmålinger på ordningen, men det er ikke så lige til.

Pyramide-ordningen er samlet set OK, som den er, men kan nok også forbedres - der kan være en tendens til overlapning. Måske kan psykologen sparre med lærerne, supervision el. lign. på individuel basis.

\section{Sammenfatning}

Projektkoordinatoren anlægger en "ekstern" betragtning på ordningen og vurderer den som uundværlig, men også omkostningstung, for skolen.

Kommunikationsproblemerne i forhold til UU ses fra en anden vinkel, idet disse vurderes som havende mulig sammenhæng med at elever måske "fortryder" deres ønske om psykologbistand ved over-gang til ny uddannelsessted. 
Udviklingsmulighederne for ordningen ses især at ligge i:

- En stærkere sparring med lærergruppen (supervision)

- En smartere indretning af ordningens fysiske lokalisering, der giver mulighed for individuel anonymisering.

\subsection{Hvad siger uddannelseslederne om ordningen?}

Der er gennemført et fokusgruppeinterview med tre uddannelsesledere fra tre forskellige afdelinger på skolen.

\section{Interviewudsagn}

Vi bruger ordningen via vore coaches, som er tilknyttet ordningen. Coachen laver en vurdering på, om psykologen skal involveres eller ej.

A: Vi bruger det rigtig meget: 12-15 stykker fra vores afdeling pr. skoleår ud af 65 elever. Der er slet ingen tvivl om, at behovet er der. Nogen har meget brug for det, andre i mindre grad. Vi ser ofte, at det handler om familiemæssige problemer, det faglige som problem er meget sjældent. Det kan også handle om misbrug af forskellig slags. Elever, der ikke fungerer - hverken i skolen eller i fritiden.

B: Det er de samme problemstillinger, men vi har færre elever. Vi bruger også coachen som indgang og dernæst vurdering om psykologen skal ind over. Smede/ industriteknikere er typisk ældre og har bedre netværk til at løse problemer i. Det er ofte det personlige, der stiller sig i vejen for det indlæringsmæssige.

Rækkefølgen er, at læreren identificerer et problem, dernæst går coachen ind, og så psykologen. Der ligger en fast ramme om dette fra skolens side. Vi kan ikke bortvise nogen, før dette er kørt igennem. Først derefter kan man udmelde en elev eller finde andre veje. Alle kender til denne arbejdsgang og bruger den konstruktivt. Lærerne er gode til at bruge denne ordning. Lærerne må ikke selv træffe beslutning om at "behandle" på en elev eller bruge ekstra tid på den enkelte.

Man må præcisere, hvor meget tid man har til en kontaktlærersamtale - ellers kan det lobe af sporet.

Der ligger en problemstilling i overleveringen fra UU - vi har brug for flere oplysninger end dem, UU må give os. Vi får ingen information om, hvis en elev har særlige problemstillinger med sig. Vi kunne ofte bruge info om, hvad eleven har i bagagen - fx elever, der er dømt eller har diagnoser.

Vi har alle elever til samtaler inden vi starter, og spørger dem, om der er noget vi skal vide. Vi kigger i Elevplan, men der står sjældent ret meget der. Det er den adgang vi har til info. I Skive kommune har de udviklet en "stafet-log" (en USB-nøgle), dvs. en form, hvor eleven selv skal overbringe det, eleven har lyst til at udlevere. Så er man uden om register-lovgivningen. Info kan også komme frem i samtaler, hvis eleven vil fortælle om det. Hvis vi ikke får de nødvendige informationer, kan det være vanskeligt at håndtere eleverne rigtigt. Nogen tager selv diagnose-papirer med, men det er et fåtal. Det samme gælder ordblindhed. Måske kunne man bruge stafet-loggen, men den er ikke uden problemer - USB-stikket kan blive væk etc. 
Ofte er meget navnebeskyttet, og så er det vanskeligt at håndtere særlig hjælp til elever. Mange elever er gode til at svare det, der fär os til at tie stille - de kender systemet og ved hvordan de skal dreje os.

C: På Hotel \& Restaurantskolen er der mange elever der bruger ordningen, nok $50 \%$ af eleverne under 25. Vi har 150 elever. Vi har $30 \%$ frafald og massiv mentorstøtte. Mange elever er svage eller udsatte - der er mange med eksamensangst og personlige problemer, manglende forældrekontakt. Mange bliver vejledt til at tro at de kan klare det - uden realisme. Mange fra STU. Der er hårdt brug for psykologordningen.

Man kan undre sig over, at så mange har behov, måske er de unge mere bevidste om, at de har brug for en psykolog, men det er nok blevet mere acceptabelt. Vi skal passe på med, at vi ikke skaber et behov hos dem.

Det er fint, de kan komme til psykolog, men der skal være måde med tingene - vi skal ikke gå for langt, men måske hellere overveje sporskifte. Elever kan lære at blive gode til at udnytte systemet. Trækker ADHD-kortet. Men der er også eksempler på, at de vokser.

Det er indiskutabelt, at psykologordningen skal være der. Men det er et problem, at det kun er unge op til 25 år, der kan bruge ordningen. Der er mange ældre elever, der har behov for støtte. Der er fx mange enlige mødre, der har behov for hjælp - hvis ordningen blev udvidet, kunne det redde mange. De unge har en mentor, det har de ældre ikke. De slås med mange problemer. Det varierer fra afdeling til afdeling, hvordan elever over 25 år har behov for stotte.

Psykologen er meget ude i undervisningsmiljøerne - er god til at holde oplæg og støtte underviserne. Men der er meget kontorarbejde, og der er elever, der føler sig udstillet, når de står på gangen. Men det er meget individuelt. Mange gange er det bedre at være $i$ klasserne og observere. Tidsfaktoren kan være et problem - det kan være svært for psykologen at finde akuttider pga. travlhed. Fx ved eksamensangst, der kan være akutte behov for støtte, der ikke kan honoreres. Psykologen er selv presset - der er et kapacitetsproblem.

Der er sket en ændring med de unge - det er blevet naturligt at gå til psykolog. Førhen vidste man godt, det var hårdt at tage en uddannelse. Det er først nu, vi er blevet bevidste om, hvor meget det betyder med den psykologiske tilgang. Det er ikke blevet lettere at være ung - mange valgmuligheder - større pres. Ingen pauser. De er ikke klar til vores system.

Men det er godt med de nye karakterkrav - det letter vores arbejde og giver bedre image. Vi kan se et bedre optag, med lige så mange tilmeldte.

\section{Sammenfatning}

Uddannelseslederne anvender ordningen i varierende grad, men vurderer den alle som en helt afgørende forudsætning for, at skolen kan have et professionelt beredskab overfor elever, der møder problemer.

Det vurderes, at kendskabet til ordningen blandt lærerne er godt, og at eksistensen af ordningen har en positiv tilbagevirkning på lærernes arbejde, dels fordi det aflaster lærerne, dels fordi lærerne får nye indsigter og ny viden i samspillet med psykologerne. 
Der foreslås følgende forbedringer:

- Et forstærket samarbejde med UU om overlevering af data om elever i form af et stafetlog, hvor eleven har sine oplysninger liggende og af egen drift overgiver dem til skolen

- En udvidelse af ordningen til elever over 25 år, der har et klart behov for lignende støttemuligheder.

\subsection{Hvad siger psykologerne om ordningen?}

Der er gennemført et interview med de to psykologer, der er tilknyttet ordningen.

\section{Interviewudsagn}

Vi arbejder på lidt forskellige vilkår og har delt arbejdsopgaverne imellem os, men grundlæggende set er vi ansat til det samme: elevsamtaler, supervision, sparring med lærere, gruppeforløb for elever etc.

Inden denne ordning blev etableret, havde skolen en aftale med psykologcenteret, således at flere forskellige psykologer kom på forskellige tidspunkter på skolen. Man ønskede en ordning med fast tilknyttede psykologer, der arbejdede på fuld tid, for at få kontinuitet $i$ det og for at få en person, der var mere integreret i skolens miljø. I den nye beskrivelse kom der ekstra aspekter af arbejdet til: erfaringsudveksling, konferencer og udvikling af et screeningsredskab. Disse nye opgaver gjorde det nødvendigt med en ekstra psykolog tilknyttet.

Indholdsmæssigt er der stor parallelitet $i$ det arbejde vi har lavet fra ordningens start og til nu. Men der er en tendens til, at flere elever opsøger ordningen, og at flere lærere henviser elever til ordningen. Nok fordi ordningen med årene har fået større synlighed på skolen. På handelsskolen er der en tendens til at flere HHX'ere bruger ordningen sammenlignet med HG'ere. Det skyldes nok en kulturforskel, på den måde at HHX'erne er mere tilbøjelige til at "gemme på" deres problemer og derfor oparbejder et behov for støtte.

Kontaktlærerne er gradvist blevet bedre til at henvise til os, fordi de nu kender og respekterer ordningen. Det er positivt, at vi får fat i flere elever med tendens til at gemme på problemer - både elever og lærere er blevet mere modige og åbne med tiden. Måske er der en tendens til, at jo højere uddannelsesniveau, desto større tendens til at "polere facaden".

Der kan være år, hvor problemerne er mere massive end andre, men grundlæggende set er problemstillingerne de samme fra år til år, og oplevelsen er, at forholdsvis få samtaler kan gøre en stor forskel. Der kan være tilfælde, hvor der er ret komplicerede problemer, hvor mange aktører skal involveres, men som oftest kan vi udrette meget med enkle midler.

De typiske problemer er: koncentration, motivation, lavt selvværd, tristhed/depression, angst, familieproblemer, sociale problemer (konflikter), ensomhed, misbrug samt diagnoser. Elever kan have det svært fagligt, blive mobbet, men som oftest er det ting, der ligger rundt om det skolefaglige. Det er disse problemer, der skal løses før det faglige kan fungere.

Samarbejdet med forældre er vokset i de år, der er gået - der er forældre, der bruger 
ordningen meget, dvs. selv henvender sig. UU-samarbejdet og samarbejdet med læger/ psykiatere er ligeledes voksende.

Der er ingen tvivl om, at behovet for ordningen er der, og at behovet er voksende, men det er naturligvis svært at måle effekten af ordningen. Vi mener tydeligt at kunne se, at ordningen gør en forskel, men vi har ikke kalkulationer på, hvad det $i$ tal betyder for fastholdelse og gennemførelse.

På lærersiden oplever vi en stor tryghed $i$, at nogen kan tage over, når problemerne bliver store, at man kan henvise til en anden type faglighed end ens egen. Lærerne kan koncentrere sig om deres undervisning, når de ved, at nogen tager sig af de elevproblemer, de er stødt på. Der er mange lærere, der lige kommer forbi og vil vende en problemstilling, ligesom vi kan intervenere med konflikthåndtering og andre ting i klasserne. Dette er et ganske stort felt. Det kan også handle om at få klassefællesskabet til at fungere, ligesom vi laver gruppeforløb af forskellig art.

Ordningen er meget fleksibel indrettet, idet vi arbejder på at nedbringe frafaldet og derudfra kan tilrettelægge meget af arbejdet selv. Den eneste restriktion er, at elever over 25 år ikke kan bruge ordningen - det er et kæmpe problem. Dette er en vigtig kvalitet ved ordningen, at den er så fleksibel.

Der ligger et forbedringspotentiale $i$ at blive endnu bedre til at spotte dem, der har et behov for samtaler eller stotte, men det kræver tid at udvikle det. Elevcoachen kan nok bedre spotte elever, fordi de er tættere på eleverne i dagligdagen. Som psykolog er det sværere at være opsøgende pga. vores rolle. Alle ansatte ved, vi er her, og vi introducerer os $i$ klasserne ved årets start, men det burde være sådan, at ingen kunne forlade stedet uden at have været $i$ kontakt med os. Screeningsredskaberne er et vigtigt redskab i denne sammenhæng. Her ligger en optimeringsmulighed, $d v s$. vi kan få fat i flere elever med behov for støtte.

Det er svært at komme mere ud over rampen, dvs. involvere sig i undervisningen - det er en delikat balance mellem at være til rådighed og være opsøgende. Vores "øjne" ligger hos coachene. Vi har også en tavshedspligt at tage hensyn til og kan ikke være super udfarende.

Hvis der var mere tid til rådighed, kunne det være fint at være mere på lærerværelserne fx $i$ det store spisefrikvarter - sidde der og få snakket med lærerne. Det kunne nok forbedre kontakten til lærerne med en fastere struktur. Lige nu er det uoverskueligt at gøre. Det er vigtigt at gøre sig tilgængelig - det giver resultater på lang sigt.

Vi kunne sagtens give input til pædagogiske sporgsmål, fx indretning af et nyt ungemiljø efter reformen, eller kurser for lærere i kollegial sparring. Introduktionsture - hvordan? Gruppeprocesser - hvordan? Der er mange psykologkompetencer, der kunne komme i spil på andre fronter end dem, vi arbejder på nu. Implementeringsovervejelser/ læreprocesser er et andet aspekt. Eller i forbindelse med HR-funktioner? Eller mere overordnet organisatorisk. Man kan nok ikke se vores kompetencer fuldt ud i organisationen. Er organisationen interesseret $i$ dette? Opgaven er ret snæver lige nu, men den kan bredes ud.

Måske kunne man arbejde mere med forløb når klasserne starter op - dvs. for-forløb, inden de starter op: snakke fællesskaber og stolthed. Der er behov for at få rettet kursen ind, inden undervisningen går i gang. Få taget brodden af den dårlige adfærd fra starten. Miljøet kan blive for hårdt for mange, og det kunne vi nok arbejde med. Ting bliver ofte sluppet og der er behov for at følge op på ting. 
Man kunne også arbejde mere i forhold til lærerne og gruppeprocesser i forhold til en god start på skolen. Der kører projekter (in-team) hvor vi ikke er involveret. Man har et billede af, at psykologer er nogen, der snakker med elever, der er kede af det i individuelle samtaler. Men kompetencerne hos os er meget bredere. Vi kan understøtte og give struktur til mange ting - fx mentorforløb. Psykologfaglig viden kan bruges på mange planer.

Vi kunne fint supervisere nye lærere, men lige nu har de ældre kolleger, og det er OK. Kigge på lærerpersonlighed og roller. Være erstatning for praktikvejledere - eller supplement til dem.

Der ligger et problem i "grædemuren" hvor eleverne venter - der bør findes andre løsninger. Det er ikke godt at være udstillet som "behandlingskrævende". Psykologens faciliteter er heller ikke optimale.

Vi løser dybest set en opgave for regionen og undgår megen psykiatri - måske burde regionen overveje at finansiere ordningen her. Vi loser mange problemer, der senere kan blive meget omkostningskrævende. Fx stoppe elever på femte grundforløb. Vi kan få øje på ting, som andre personalegrupper ikke får øje på. Coaching kan hjælpe af og til, men vi kan gøre noget ved de dybere problemstillinger.

Der skal findes ny finansiering - evt. for egne midler. Det er svært at lave en økonomisk evaluering af ordningen, da så mange faktorer spiller ind - kontanthjælpsreformer mv., det må kunne svare sig - hvis man ser på det helt overordnet.

Andre skoler forsøger sig med modeller, hvor skoler og kommuner går sammen om at finansiere en ordning, dette kunne måske være inspiration. Det er påfaldende, at andre institutioner har psykologer tilknyttet, mens der hvor behovet måske er størst, er det sværest at etablere. Bliver det set som svaghedstegn at have en ordning? Hvilken logik ligger bag dette?

Det må være godt for bundlinjen! Det handler om værdier versus økonomi.

Hvis man vil fortsætte ordningen, skal det være i den nuværende form, dvs. integreret $i$ skolens hverdag - det er den bedste model. Vi kender kolleger, der arbejder $i$ andre modeller, der ikke har samme kvalitet.

Hvis psykologen fx kommer hver fjortende dag, kan det måske være ligegyldigt - man skal være der, når tingene sker. Ellers kan det måske være for sent. Vi har i princippet åbent 24/7.

Det har en stor betydning for synligheden, at vi er her på skolen og bliver en del af miljøet - det vil en ekstern ikke kunne. Eleverne ser os og lærer os at kende - det skaber tryghed og tilgængelighed.

Vi samarbejder sporadisk med bedsteforældrene - det kunne måske udbredes. De kender ordningen godt og vi har holdt kurser for dem.

\section{Sammenfatning}

Psykologerne påpeger, at ordningen med tiden er blevet mere kendt, anerkendt og anvendt.

Ordningen opleves som værende meget vigtig i henseende til fastholdelse af elever, og der spores en tendens til at såvel forældre som UU bruger ordningen mere. Selve indhol- 
det i psykologernes arbejde er i det store og hele uforandret. Indsnævringen af målgruppen til elever under 25 år vurderes som værende et stort problem.

Psykologerne peger på en række udviklingsmuligheder for ordningen:

- Et intensiveret samarbejde med coaches kan gøre spotningen af udsatte elever skarpere

- En øget tilstedeværelse på lærerværelser (kræver mere tid)

- Bistand til lærere ved opstart af nye klasser

- Anvendelse af psykologer på nye områder i organisationen: ledelses- og HR-sparring, konsulentbistand på ansøgninger og udviklingsprojekter mv.

- Udvikling af mere hensigtsmæssige adgangsforhold til psykologens kontor på autogangen

- Evt. udvidet samarbejde med "bedsteforældrene".

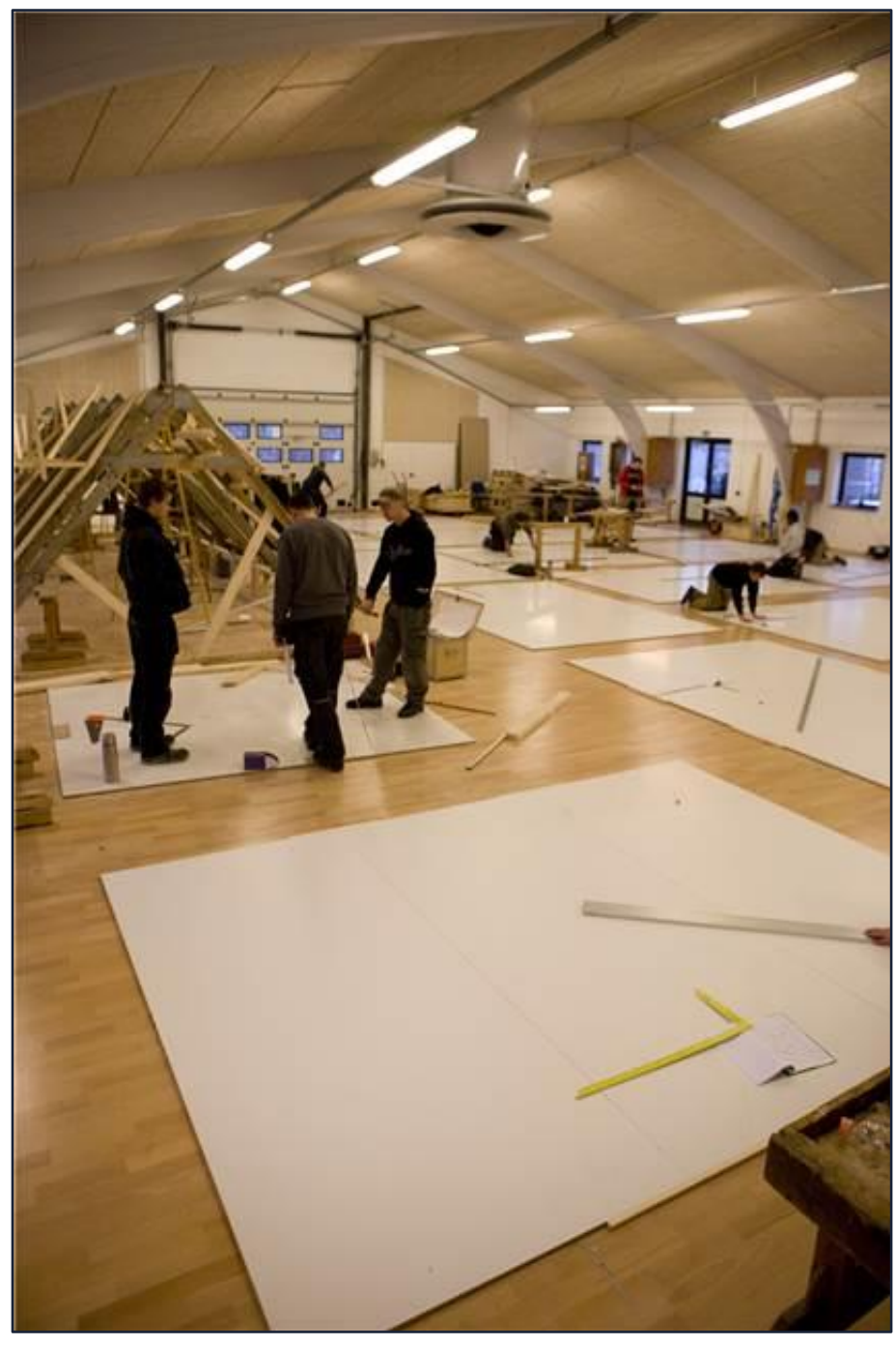




\subsection{Hvad siger coaches om ordningen?}

Der er gennemført interview med skolens to coaches.

\section{Interviewudsagn}

Der er ikke noget umiddelbart behov for at ændre i ordningens konstruktion. Vi samarbejder dagligt med psykologerne - de er vores nærmeste samarbejdspartnere.

Ordningen har vokset sig stor og stærk - vi fik forlængelse, så vi har kørt 2 x 4 år. Først trak vi psykologer ind på skolen, dernæst fik vi den nuværende ordning.

Det er en meget flittig benyttet ordning, efterhånden som den er blevet kendt. Værktøjet er hurtigt at bruge - der kan handles på ganske få timer og typisk max et par dage. Det er nok den største styrke, at vi kan levere en hurtig og professionel indsats. Samt det, at psykologerne er på stedet og er vant til målgruppen.

Der kan ikke sættes en finger på noget - alt fungerer optimalt, men vi kan spore en tendens til, at eleverne opsøger ordningen, fordi den nu en gang er der. At problemerne skaber sig selv, så at sige. Vi kan dermed overbelaste os selv lidt ved at være her - det er en slags forkælelse. De unge har vænnet sig til at kunne trække på coaches og psykologer, og det er en god ting.

Vi kunne godt tænke os, at Rusmiddelcenteret vågnede lidt mere op og tog et initiativ $i$ forhold til tilstedeværelse her på skolen - blot en dag om ugen, så vi ikke skal køre eleverne derop. De unge vil ikke derned.

Risikerer vi at sygeliggøre elever ved at have ordningen? Det kan der måske være en logik $i$, men hvad er alternativet? Hvis vi lukker det ned, bliver det meget svært at få op at køre igen.

Psykologerne har stor betydning for lærerne. Der kan være mange problemstillinger, lærerne ikke umiddelbart kan håndtere og har stort behov for sparring. Det er et stort aktiv for dem. Psykologerne gør vores arbejdsliv nemmere hver dag i kraft af det tæette samarbejde, vi har med dem. Vi beholder flere af de elever, som andre skoler ville sende videre til andre systemer i kraft af det systemiske samarbejde i Pyramiden. Der er en klar synergieffekt $i$ ordningen.

Hvis lærere har problemer med en klasse, kan vi henvise til, at psykologen kan understøtte ved at få fokus på de elever, der kan volde vanskeligheder. Med GF1s opkomst har psykologen sat en fast dag af, hvor man som lærer kan komme og sparre om de særlige udfordringer, der er ved at undervise de helt unge - det er en fin ordning. Som coaches kan vi også indgå i dette. Dette er der god læring i for os som coaches.

Samarbejdet er dejligt uformelt mellem de parter der er involveret, det er guld værd. Der er en tryghed i meget hurtigt at kunne få faglig hjælp og ikke skulle ud af huset og finde den. Det kan være hjælp til diagnoser eller misbrugsadfærd.

Psykologen er en faglig kapacitet med masser af uddannelse.

Hvis psykologen ikke var her, ville vores belastning blive væsentlig større. Det handler om ca. 200 elever om året, der har psykologsamtaler. Visse skoler kan klare sig uden psykolog, men spørgsmålet er, om ikke de går glip af den store kvalitet, at elever kan fortsætte deres påbegyndte uddannelser og ikke skulle ud og søge støtte andre steder og 
evt. derfor afbryde? Mange af de elever, der går hos psykologen, har ikke overskud til at søge hjælp uden for huset. De får alene hjælpen, fordi den er nem at gå til.

Mht. faciliteter: enkelte elever siger, at de føler sig udstillet, men det kan faktisk løses ved mere smarte aftaler. Det behøver ikke at være et problem. Det er alene et problem ved auto. På HS er det bedre. Et ventested kunne være en løsning.

Svært at finde forbedringspunkter. Tilbuddet er godt og det virker $i$ kraft af professionalisme.

Kan man beregne økonomiske effekter? Vi kan ikke gøre livskvalitet op i penge. Frafaldet er reduceret, men det er ikke sikkert, det ville stige igen tilsvarende.

Reformen har nok ikke den store betydning - problematikkerne er de samme. Det har ingen effekt på vores arbejde. Det er en voldsom start fra første skoledag - massive problemer i ungemiljøerne.

GF1-miljøerne er noget særligt og skaber måske flere problemer, end vi er vant til. Det er dygtige og engagerede lærere, men store problemer. Men der er en fed energi. Der er tilsvarende effekt på HS. Det kræver, at psykologerne har elastik, men det er nok ikke nogen god idé at specialisere psykologerne - de er og skal være brede. Der er færre GF1'ere, der har modstand mod psykolog end tidligere. Tilliden til psykologerne er god.

Vi går gerne med til psykologen sammen med eleven - og støtter eleven, hvis han alligevel ikke ønsker det. Det kan man ikke ude i byen. Vi har en tilvænningsfase, hvor de kan prøve til-det er en styrke.

Svært at pege på forbedringspunkter. Hvis midlerne var der, kunne vi have flere elevcoaches på afdelingerne, men det er de ikke. Hvis vi var der hele tiden, kunne vi bedre spotte problemerne. Vi kunne blive skarpere på at spotte og screene. Vi kan ikke løbe hurtigere, end vi gør nu.

Ordningen har haft en effekt på lærernes evne til at iagttage elever med problemadfærd og til at reducere deres bekymringer. Det har udviklet systemet. Og vi er godt kørende på kvaliteten.

Hvis den anden psykolog falder væk, bliver det meget stramt for den fuldtidsansatte.

Vi slukker ikke telefonerne, de er åbne døgnet rundt. Der skal være et beredskab-også mht. psykologen, hvis vi skal arbejde helhedsorienteret. Kl. 15 overgår ansvaret til kommunen, når vi lukker her. Vi kan kontakte psykologen efter skoletid, hvis der er noget, men eleverne kan ikke. Det er ikke noget vi taler så meget om. Det bliver ikke misbrugt.

UU kender udmærket ordningen, men der kan gå kludder i kommunikationen af og til. Vi tjekker grundigt på alle med uddannelsespålæg. Men ikke altid $i$ kontakt med UUvejlederne.

Vi har orienteret UU på møder om Pyramiden, men det kan sikkert forbedres. UU kan blot ringe til os, så aktiverer vi psykologordningen. UU er blevet opfordret til at ringe direkte til os. 


\section{Sammenfatning}

De interviewede coaches vurderer ordningen som et meget stærkt redskab i skolens fastholdelsesarbejde. Ordningen er fleksibel, godt indlejret i skolens miljø og nem at gå til for alle parter.

Det er umiddelbart svært at pege på forbedringsmuligheder, men der peges på en bedre integration af rusmiddelcentret på skolen - og i samarbejde med psykologen. Dette vil kunne aflaste coaches og styrke elevernes adgang til støtte. Problemet med "udstilling" af elever kan løses ved smartere aftale med eleverne, siges der.

Reformen og de nye ungemiljøer vil antagelig kalde på mere psykologfaglig indsats der, men foreløbig tackles problemerne i den nye ordning.

Ordningen medvirker til at udvikle lærernes iagttagelsesevne overfor eleverne og gøre lærerne skarpere til at spotte problemstillinger.

Den mislykkede kommunikation med UU er umiddelbart svær at forklare - UU burde have den tilstrækkelige systemindsigt til at kunne bruge ordningen optimalt.

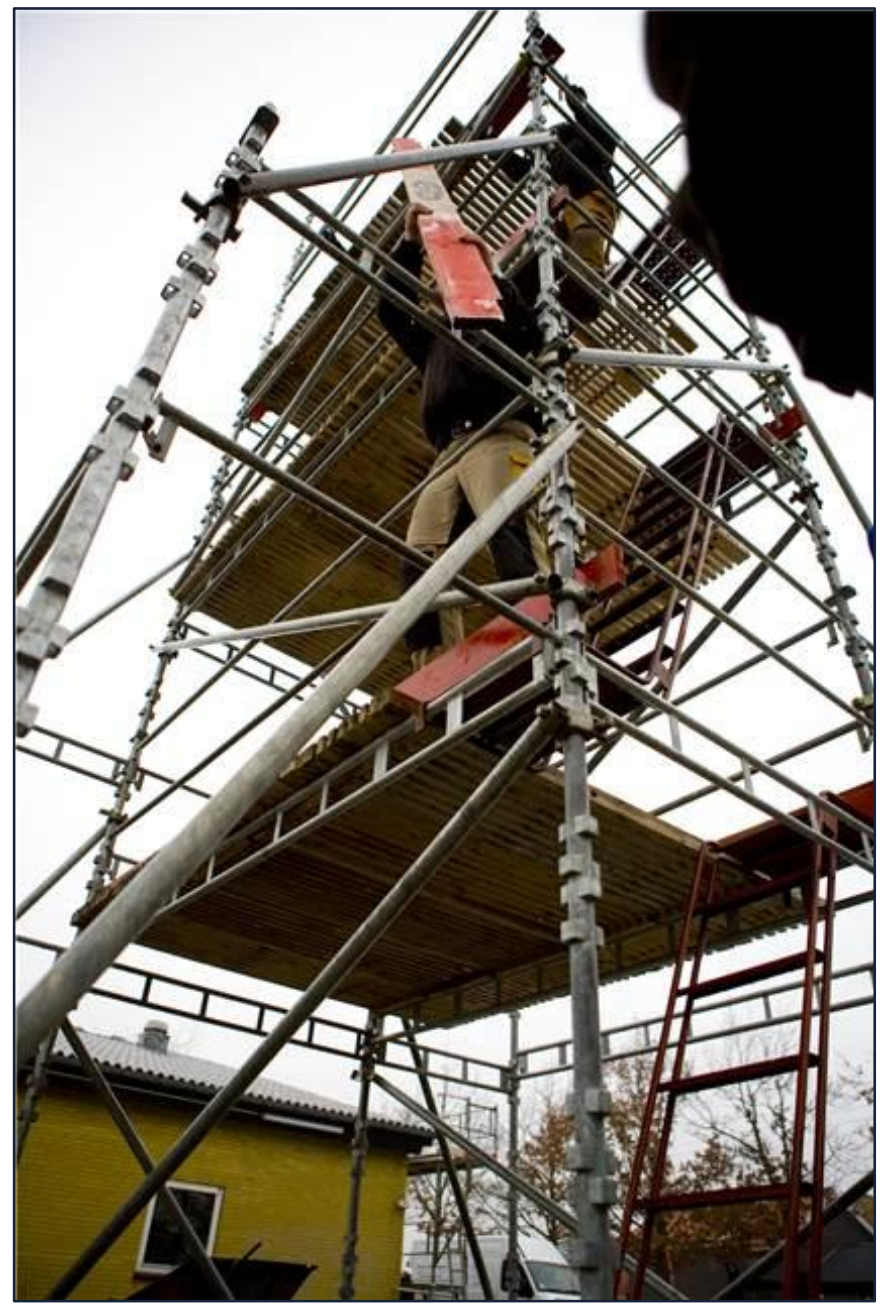




\subsection{Hvad siger skolens ledelse om ordningen?}

Der er gennemført et interview med en repræsentant for skolens ledelse

\section{Interviewudsagn}

Ordningen med $1+1 / 2$ psykolog har udviklet sig meget over tid. Der var i starten meget skepsis i huset: kunne det misbruges?

Dette blev dog hurtig afkræftet og psykologen har haft en god pædagogisk indgang til arbejdet og er blevet brugt af såvel lærere som ledelse. Det har været super godt at få ordningen etableret og den er blevet "afdramatiseret" med tiden. Vi kan se af psykologens årsrapport, at det ofte er små ting, der skal til for at løse elevproblemer - det handler ofte om nervøsitet, manglende motivation og mangel på overblik over ens tilværelse.

Lærerne henviser ikke i ublu omfang til psykologen, og elevcoachen tager meget af arbejdet. For ledelsen har det været uvurderligt, og vi kan kun frygte, hvad der sker, hvis eller når vi holder op. Måske kan vi forlænge ordningen lidt, men det er svært at finde finansiering på lang sigt. Det ville være ideelt at få indtænkt ordningen i den pædagogiske strategi, men finansieringen er det helt store problem. Vi har søgt tre-fire steder, men uden held. Det er meget ærgerligt.

Afdelingerne har taget vel imod ordningen, det har med at gøre hvem der spotter eleverne. Gymnasie-afdelingen var mest tilbageholdende, men er kommet godt med. Lærerne magter typisk ikke at løse personlige problemer, så ordningen er fin som understøttelse af dem. Det har meget med åbenhed at gøre.

Der er grænser for hvad lærerne kan løfte af opgaver. Lærere får måske fat i noget, der ikke er hensigtsmæssigt at arbejde med - for meget dukker op. Elevcoaches kan på den anden side måske opdyrke for mange problemer - ved at sætte lys på for meget. Så er det tacklet forkert.

Mange af de elever der kommer med "ondt i livet" er forvirrede og kan ikke finde retning. Det er let at blive rubriceret som lettere deprimeret, når man bliver testet. Vi har ikke kunne effektevaluere, men det ville være interessant at gore. Frafaldet er reduceret fra 30 til $13 \%$, men vi kan jo ikke finde den direkte årsag. Det har været nemmere for EUD at gå ind til ordningen - der ligger nogle holdningsforskelle der i forhold til gymnasiet. Måske synes gymnasiet, det er lidt overflødigt med psykologbistand?

Kunne lærerne blive superviseret af psykologen? Ja, men vi har psykologer tilknyttet lærerne, og vi adskiller de to ordninger. Det er det klogeste. Men supervisering af lærernes undervisning er en mulighed, der har været prøvet.

Vi ved ikke helt hvad andre skoler gør, men vi undersøger det. Det er et meget forskelligt billede.

De sårbare skal ikke været ret sårbare i det nye system, før det går galt - de kan ikke forlænges i GF1. Det bliver både GF1 og 2 der får behov for støtte, det er der ingen tvivl om. De har svært ved at være i fællesskaber og danne gode relationer. De voksne er der ikke til at dysse de unge lidt ned. Så ungdomsmiljøerne bliver en stor udfordring psykologisk set.

Ordningen er evalueret løbende, og vi har småjusteret undervejs - den skal stadig have fokus på samtaler og fastholdelse. Åben-dør-ordningen er lukket lidt op og ned over tidvi har gjort det rigtige, synes vi. Får vi en bevilling, vil vi se på ændringer, men intet er helt 
oplagt. Måske er det oplagt at bruge psykologen mere i forhold til lærergruppen på særlige områder. Lærerne mangler ofte værktøjer, fx i forhold til ADHD. Man kunne fint udvikle en værktøjskasse på dette område.

Vi har som intention at arbejde med den enkelte elevs behov, og her har psykologen en vigtig rolle. Udviklingen af det faglige via det personlige og sociale er et helt centralt indsatsområde. Psykisk sårbare elever er ikke nødvendigvis fagligt svage elever. Elever kan være for præstationsorienterede og dermed sårbare.

Mht. kommunikationen med UU: kontaktlærere burde kende samspilsmulighederne, men muligvis foreligger der et kommunikationsproblem på dette felt?

Det er forståeligt, at elever kan føle sig udstillet, når de venter på at komme til samtaler vi bor nok se på, om indretningen af dette skal revideres. Der er stor synlighed, som det er indrettet nu, men det ville også være mærkeligt, hvis det var helt skjult.

\section{Sammenfatning}

Ordningen vurderes som værende meget velfungerende, professionelt drevet og stærkt påkrævet, ikke mindst set i lyset af de ændringer der vil følge af reformen med egentlige ungemiljøer, hvor voksnes socialiserende virkning på de helt unge vil aftage.

Ordningen bør videreføres, men det er en udfordring at finde finansiering til den.

Der ses udviklingsmuligheder i følgende:

- Psykologer kan intensivere samarbejdet med lærere - supervision

- Ordningen skal indtænkes skarpere i skolens kommende revidering af den pædagogiske strategi

- Der skal udvikles på adgangsforholdene til ordningen

- Det skal undersøges, hvor nye muligheder for ekstern finansiering måtte ligge.

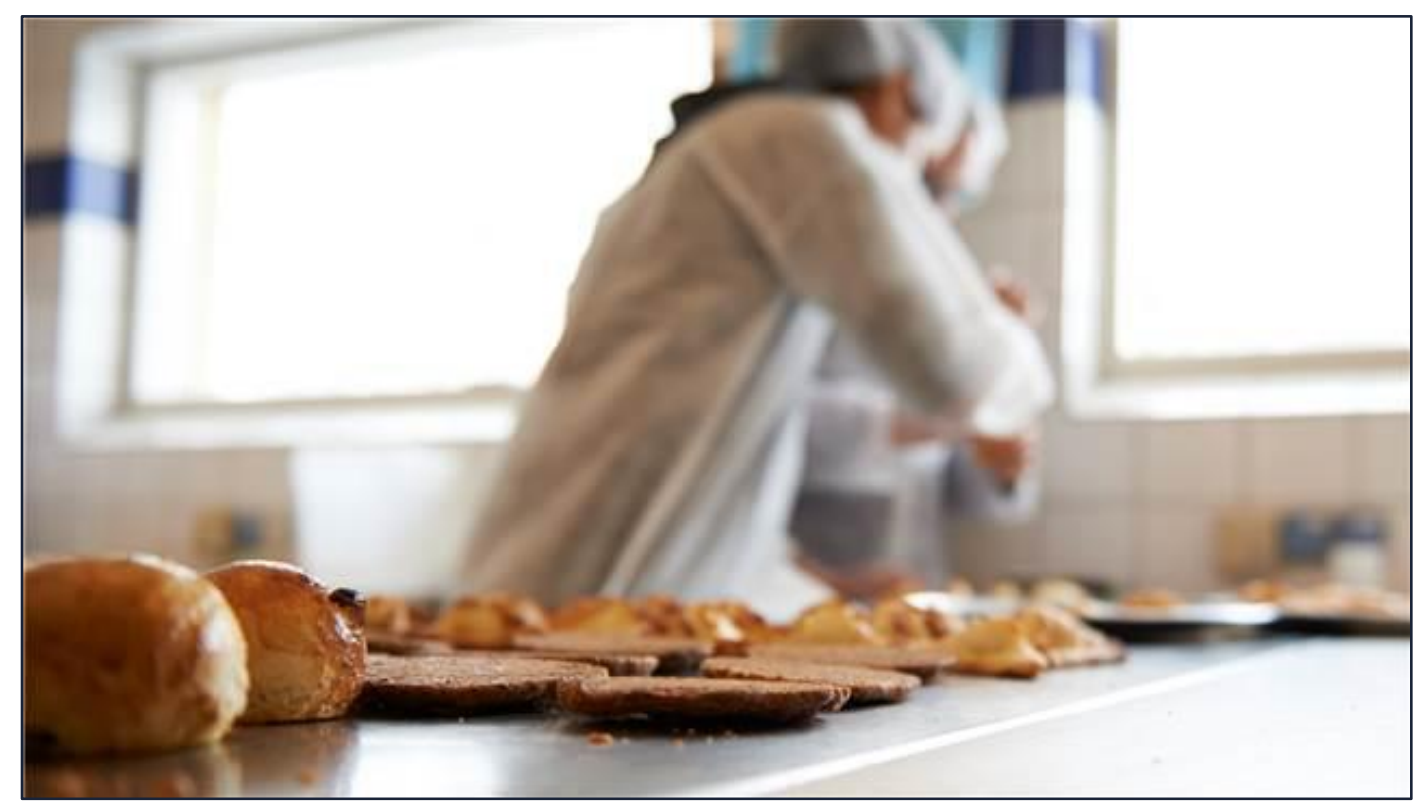




\section{Afrunding og konklusion}

Med det gennemførte 360-graders-eftersyn af psykologordningen på Mercantec må man konkludere, at skolen råder over en velfungerende ordning, der arbejder på et højt fagligt niveau og skaber brugbare resultater. Elever oplever imødekommenhed, empati og får en støtte, der bringer dem videre. Forældre oplever, at deres unge får en vigtig støtte i vanskelige situationer, ligesom skolens øvrige personale i psykologordningen råder over en aflastnings- og supportfunktion, der bidrager til, at de kan løse deres opgaver med større kvalitet.

Ordningen opleves samstemmende som fleksibel, professionel og i øjenhøjde med elevernes behov for, hvornår og hvordan støtten skal gives, og der kan kun identificeres to egentlige problemområder ud fra de foreliggende data:

1) Ordningen er kendetegnet ved at adgangs/venteforhold kan tendere til at "udstille" elever, der ellers helst ville være anonyme i denne rolle

2) UU påpeger at anmodninger om bistand til elever i overgangssituationen fra grund- til erhvervsskole kan "blive væk" eller ikke nå frem til rette vedkommende

Forskellige aktører peger på - få - egentlige udviklings- eller forbedringsmuligheder. Det drejer sig i al væsentlighed om følgende:

- At der gennemføres en "gennemstrømningsanalyse", der kan vise hvor kommunikation omkring elever med støttebehov KAN kikse

- At der følges bedre op på de elever, der modtager psykologbistand, og at der herefter gives feedback til UU om udfaldet heraf

- At skolen øger indsatsen for ( $\mathrm{fx}$ via bedre skiltning) at eleverne kan få kendskab til ordningens eksistens og dermed klædes bedre på til af egen drift, at kunne bruge tilbuddet

- Et forstærket samarbejde med UU om overlevering af data om elever i form af et stafetlog, hvor eleven har sine oplysninger liggende og af egen drift overgiver dem til skolen

- En udvidelse af ordningen til elever over 25 år, der har et klart behov for lignende støttemuligheder

- Psykologer kan intensivere samarbejdet med lærere, fx i form af supervision

- Bistand til lærere ved opstart af nye klasser

- Ordningen skal indtænkes skarpere i skolens kommende pædagogiske strategi

- Der skal udvikles på adgangsforholdene til ordningen

- Det skal undersøges hvor nye muligheder for ekstern finansiering måtte ligge

- Et intensiveret samarbejde med coaches kan gøre spotningen af udsatte elever skarpere

- En øget tilstedeværelse på lærerværelser

- Anvendelse af psykologer på nye områder i organisationen: ledelses- og HR-sparring, konsulentbistand på ansøgninger og udviklingsprojekter mv. 
- Evt. udvidet samarbejde med "bedsteforældrene".

Disse potentielle udviklingsfelter for psykologordningen indgår således som led i et samlet billede af en ordning, der af samtlige aktører i og omkring ordningen betegnes som velfungerende, uundværlig og med højt kvalificerede medarbejdere, der yder en kompetent og fleksibel service.

Holdningen hos alle interviewede er således at ordningen er værdifuld og bør fortsætte, men udvikles gennem de påpegede forbedringspunkter. Ikke mindst set i lyset af, at reformen af erhvervsuddannelserne efter alt at dømme vil medføre nye og måske større udfordringer, fordi især de nye ungemiljøer vil rumme psykologisk-pædagogiske problemstillinger, der kalder på muligheden for kvalificerede støtteforanstaltninger.

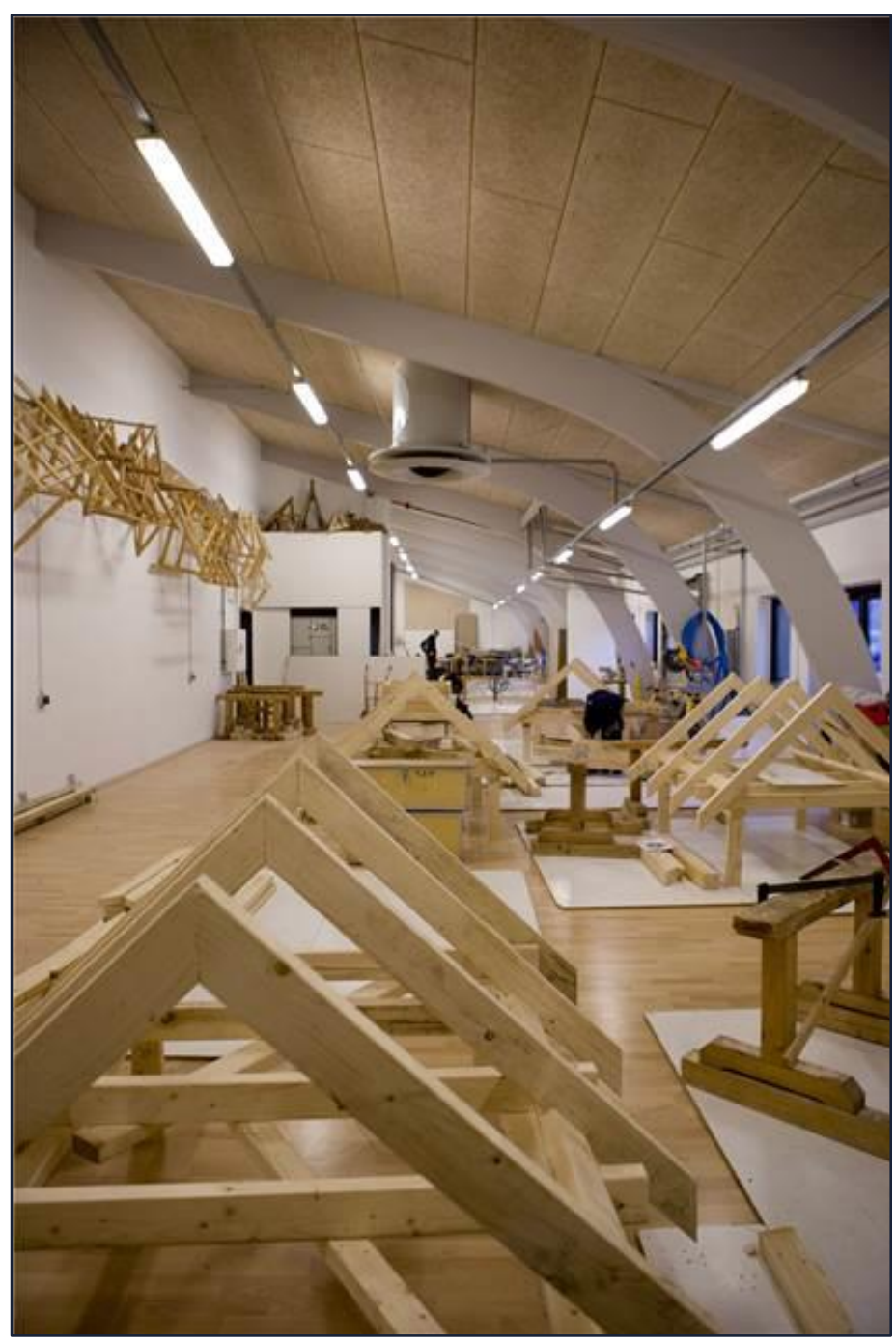




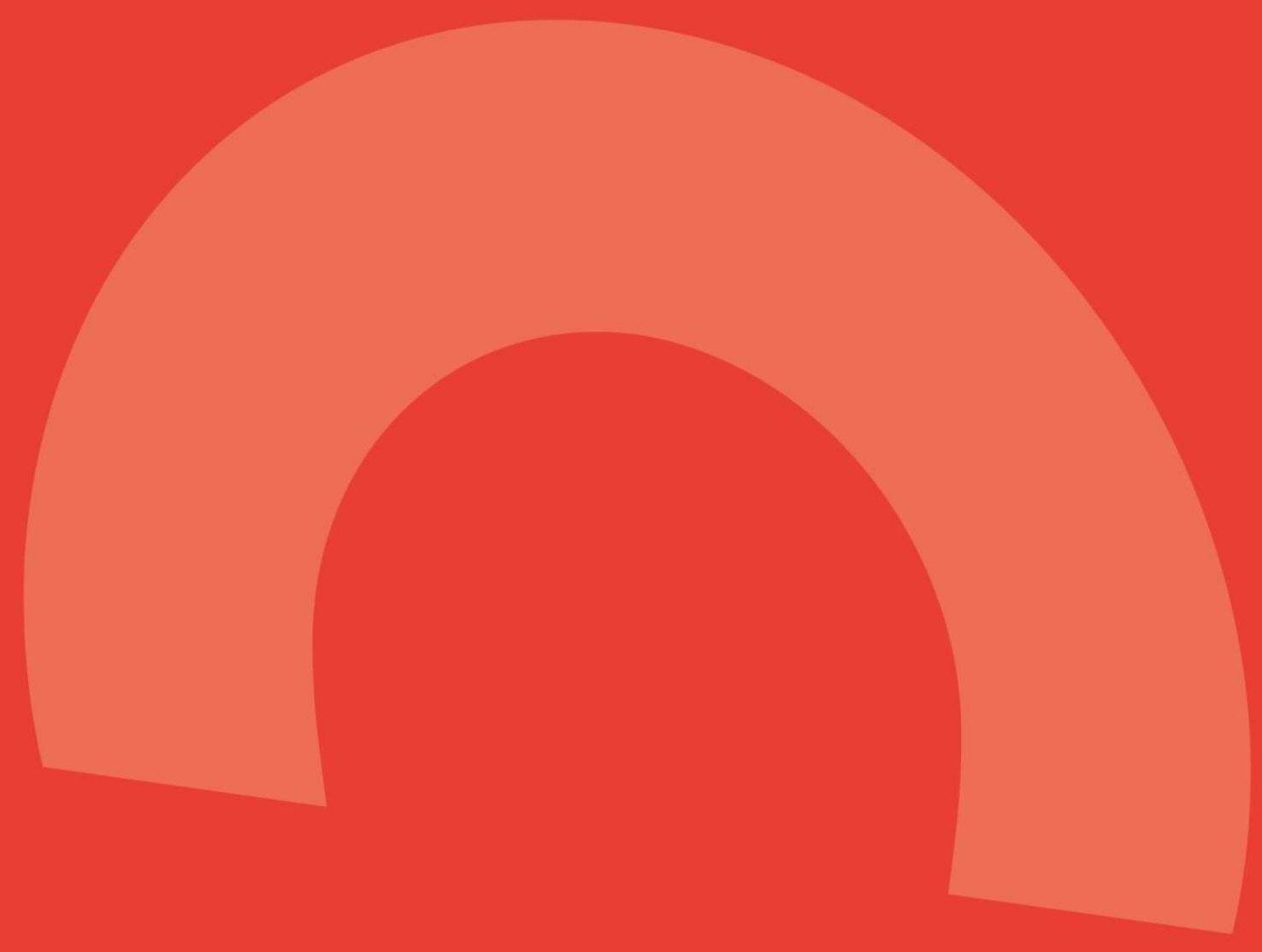

Professionshøjskolen Metropol

www.phmetropol.dk 